\title{
Rare Disasters and Asset Markets in the Twentieth Century
}

\section{Citation}

Barro, Robert J. 2006. Rare disasters and asset markets in the twentieth century. The Quarter Journal of Economics 121, no. 3: 823-866.

\section{Published Version}

http://dx.doi.org/10.1162/qjec.121.3.823

\section{Permanent link}

http://nrs.harvard.edu/urn-3:HUL.InstRepos:3208215

\section{Terms of Use}

This article was downloaded from Harvard University's DASH repository, and is made available under the terms and conditions applicable to Other Posted Material, as set forth at http:// nrs.harvard.edu/urn-3:HUL.InstRepos:dash.current.terms-of-use\#LAA

\section{Share Your Story}

The Harvard community has made this article openly available.

Please share how this access benefits you. Submit a story.

Accessibility 


\title{
RARE DISASTERS AND ASSET MARKETS IN THE TWENTIETH CENTURY*
}

\author{
ROBERT J. BARRo
}

The potential for rare economic disasters explains a lot of asset-pricing puzzles. I calibrate disaster probabilities from the twentieth century global history, especially the sharp contractions associated with World War I, the Great Depression, and World War II. The puzzles that can be explained include the high equity premium, low risk-free rate, and volatile stock returns. Another mystery that may be resolved is why expected real interest rates were low in the United States during major wars, such as World War II. The model, an extension of work by Rietz, maintains the tractable framework of a representative agent, timeadditive and isoelastic preferences, and complete markets. The results hold with i.i.d. shocks to productivity growth in a Lucas-tree type economy and also with the inclusion of capital formation.

The Mehra-Prescott [1985] article on the equity risk-premium puzzle has received a great deal of attention. An article published three years later by Rietz [1988] purported to solve the puzzle by bringing in low-probability economic disasters, such as the Great Depression. I think that Rietz's basic reasoning is correct, but the profession seems to think differently, as gauged by the continued attempts to find more and more complicated ways to resolve the equity-premium puzzle.

I think the major reason for skepticism about Rietz's argument is the belief that it depends on counterfactually high probabilities and sizes of economic disasters. Thus, a key aspect of my empirical analysis is the measurement of the frequency and sizes of the international economic disasters that occurred during the twentieth century. The three principal events are World War I, the Great Depression, and World War II, but post-World War II depressions have also been significant outside of OECD countries. My analysis of these events suggests a disaster probability of 1.5-2 percent per year with a distribution of declines in per capita GDP ranging between 15 percent and 64 percent.

I construct a model of the equity premium that extends Lucas [1978], Mehra and Prescott [1985], and Rietz [1988]. I then cali-

* My interest in this topic began with a discussion of Marty Weitzman's paper in Harvard's macroeconomics seminar. I am grateful for comments from Alberto Alesina, Marios Angeletos, Olivier Blanchard, John Campbell, Eugene Fama, Xavier Gabaix, Hans Genberg, Michael Golosov, Kai Guo, Fatih Guvenen, Robert Hall, Lars Hansen, Narayana Kocherlakota, David Laibson, Robert Lucas, Gregory Mankiw, Raj Mehra, Casey Mulligan, Sergio Rebelo, Jeremy Siegel, Aleh Tsyvinski, Martin Weitzman, Marc Weidenmier, Ivan Werning, and participants of various seminars.

๑ 2006 by the President and Fellows of Harvard College and the Massachusetts Institute of Technology.

The Quarterly Journal of Economics, August 2006 
brate the model using the observed probability distribution for economic disasters in the twentieth century. The model's solution gets into the right ballpark for explaining the equity-premium and related asset-market puzzles, such as the low real rate of return on government bills. Another mystery that may be resolved is why expected real interest rates were low in the United States during major wars, such as World War II.

\section{A Lucas Tree Model with Rare Disasters}

\section{I.A. Setup of the Model}

Following Mehra and Prescott [1985], I use a version of Lucas' [1978] representative-agent, fruit-tree model of asset pricing with exogenous, stochastic production. Output of fruit in period $t$ is $A_{t}$. In the initial version of the model, the number of trees is fixed; that is, there is neither investment nor depreciation. Since the economy is closed and all output is consumed, consumption $C_{t}$ equals $A_{t}$.

One form of asset in period $t$ is an equity claim on period $t+$ 1 's output, $A_{t+1}$. This asset is a claim on one dividend, not the tree itself. However, because of the i.i.d. assumptions made later, the expected rate of return on this one-period claim will be the same as that on a tree claim. If the period $t$ price of the one-period equity claim in units of period $t$ 's fruit is denoted by $P_{t 1}$, the one-period gross return on this asset is

$$
R_{t 1}^{e}=A_{t+1} / P_{t 1} .
$$

I assume that property rights are secure, so that the claim ensures ownership over next period's fruit $A_{t+1}$ with probability one.

There is also an asset that guarantees a risk-free return in normal times but on which partial default occurs on rare occasions. I view this asset as a government bill. The face return delivered in normal times is denoted by $R_{t 1}^{f}$. I detail later the assumptions about default probability.

The representative consumer maximizes a time-additive utility function with isoelastic utility:

$$
U_{t}=E_{t} \sum_{i=0}^{\infty}\left[e^{-\rho i} \cdot u\left(C_{t+i}\right)\right],
$$


where

$$
u(C)=\left(C^{1-\theta}-1\right) /(1-\theta) .
$$

In these expressions, $\rho \geq 0$ is the rate of time preference, and $\theta>$ 0 is the coefficient of relative risk aversion and the reciprocal of the intertemporal elasticity of substitution for consumption.

The usual first-order optimization condition implies that

$$
u^{\prime}\left(C_{t}\right)=e^{-\rho} \cdot E_{t}\left[u^{\prime}\left(C_{t+1}\right) \cdot R_{t 1}\right],
$$

where $R_{t 1}$ is the one-period gross return on any asset traded at date $t$. Using (4), substituting $C=A$, and replacing $R_{t 1}$ by the formula for $R_{t 1}^{e}$ in (1) yields

$$
\left(A_{t}\right)^{-\theta}=e^{-\rho} \cdot\left(1 / P_{t 1}\right) \cdot E_{t}\left[\left(A_{t+1}\right)^{1-\theta}\right] .
$$

Therefore, the price of the one-period equity claim is given by

$$
P_{t 1}=e^{-\rho} \cdot\left(A_{t}\right)^{\theta} \cdot E_{t}\left[\left(A_{t+1}\right)^{1-\theta}\right] .
$$

The log of output (productivity) evolves as a random walk with drift,

$$
\log \left(A_{t+1}\right)=\log \left(A_{t}\right)+\gamma+u_{t+1}+v_{t+1},
$$

where $\gamma \geq 0$. The random term $u_{t+1}$ is i.i.d. normal with mean 0 and variance $\sigma^{2}$. This term gives results similar to those of Mehra and Prescott. I assume that $\gamma$ and $\sigma$ are known. Weitzman [2005] argues that learning about $\sigma$ is important for asset pricing-this idea is not pursued here. However, Weitzman's model generates "fat tails" that have effects analogous to rare disasters.

The random term $v_{t+1}$ picks up low-probability disasters, as in Rietz [1988]. In these events, output jumps down sharply, such as in the Great Depression. The probability of a disaster is the known amount $p \geq 0$ per unit of time, where $p$ is a constant. The probability of more than one disaster in a period is assumed to be small enough to neglect-later, the arbitrary period length shrinks to zero. If a disaster occurs, output contracts proportionately by the fraction $b$. The idea is that the probability of disaster in a period is small but $b$ is large. The distribution of $v_{t+1}$ is given by

$$
\begin{gathered}
\text { probability } e^{-p}: v_{t+1}=0, \\
\text { probability } 1-e^{-p}: v_{t+1}=\log (1-b) .
\end{gathered}
$$

The contraction proportion $b$-the size of the downward jump in 
output-is a random variable, calibrated later to accord with the distribution of observed economic depressions during the twentieth century.

The specification for $v_{t}$ creates negative skewness in the distribution of $A_{t+1}$, because disasters are not offset in a probabilistic sense by bonanzas. However, the asset-pricing results are similar for a symmetric specification in which favorable events of size $b$ also occur with probability $p$. With diminishing marginal utility of consumption, bonanzas do not count nearly as much as disasters for the pricing of assets.

\section{I.B. Economic Disasters in the Twentieth Century}

Actual and potential economic disasters could reflect economic events (the Great Depression, financial crises), wartime destruction (world wars, nuclear conflicts), natural disasters (tsunamis, hurricanes, earthquakes, asteroid collisions), and epidemics of disease (Black Death, avian flu). I use the twentieth-century history of economic disasters to assess disaster probabilities, sizes of contractions, and default probabilities.

A prototype economic disaster is the Great Depression, which featured a large, global economic decline that did not trigger default on assets such as government bills. ${ }^{1}$ However, from the standpoint of sizes of world economic disasters in the twentieth century, war has been more important than purely economic contractions. For the United States, at least since 1815 and aside from the Confederacy during the Civil War, wars did not involve massive destruction of domestic production capacity. In fact, some wars, especially World War II, featured robust economic activity. However, the history for many other OECD countries is very different, notably for World Wars I and II.

Part A of Table I shows all episodes of 15 percent or greater decline in real per capita GDP in the twentieth century for twenty OECD countries covered over a long period by Maddison [2003]. ${ }^{2}$

1. In the United States, the rise in the gold price and abrogation of gold clauses in bond contracts may be viewed as forms of partial default; see McCulloch [1980].

2. The present model lacks investment, government purchases, and net exports; therefore, GDP and consumption coincide. More generally, it would be preferable to measure consumption rather than GDP to relate the data to the model. However, GDP data are much more plentiful for long-term analyses. 
This group comprises the major economies of Western Europe plus Australia, Japan, New Zealand, and the United States. ${ }^{3}$

In the model, an economic disaster corresponds to a downward jump in per capita GDP at an instant of time. In the data, the declines are stretched out over time, such as 1939-1945 for some countries during World War II. In using the data to calibrate the model, there is no reason to focus on falls in per capita GDP over a fixed interval of time, such as a calendar year (over which the data happen to be assembled). Table I measures declines in per capita GDP over consecutive years, such as 19391945. My reasoning is that the start of a war, such as World War II for Western Europe in 1939, puts a country into a regime where, with much higher probability than usual, output falls sharply over the next several years. The exact outcome depends on whether the country wins or loses, the extent of destruction of property and life, and so on. These features and the length of the war are unknown initially.

A reasonable way to model this kind of disaster is that, with probability $p$ per unit of time, a country enters into a war state, which leads to an ultimate contraction in per capita GDP by the proportionate amount $b$. The duration of the disaster-for example, one year or five-may be secondary. (In a later section I assess this effect by considering the length of the period in the model.) Therefore, the cumulative decline in per capita GDP during each war should provide a reasonable estimate of $b$. The associated disaster probability corresponds to the number of wars (say, per century) that featured these sharp cumulative contractions, rather than the fraction of years in which a country was involved in this kind of war. I take a similar approach to purely economic depressions, such as the Great Depression. These events typically involve financial crises, which are similar in some respects to wars.

Ten of the contractions in part A of Table I were associated

3. Kehoe and Prescott [2002] extend the concept of a depression to cases where the growth rate of real per capita GDP fell well below the historical average for an extended period. Thus, they classify as depressions the periods of slow economic growth in New Zealand and Switzerland from the 1970s to the 1990s. Hayashi and Prescott [2002] take a similar approach to Japan in the 1990s. These experiences can be brought into the present framework by allowing for a small probability of a substantial cutback in the productivity growth parameter $\gamma$. However, the potential for this kind of change turns out not to "work," becausewith the parameter $\theta$ in the reasonable range where $\theta>1-a$ decline in $\gamma$ (applying to the whole world) turns out to raise the price-earnings ratio for stocks. Also, the equity premium is independent of $\gamma$. 
TABLE I

Declines of 15 Percent or More in Real Per Capita GDP

\begin{tabular}{|c|c|c|c|}
\hline \multicolumn{4}{|c|}{$\underline{\text { Part A: Twenty OECD Countries in Maddison [2003] }}$} \\
\hline Event & Country & Years & $\begin{array}{c}\% \text { fall in real } \\
\text { per capita } \\
\text { GDP }\end{array}$ \\
\hline \multirow[t]{8}{*}{ World War I } & Austria & 1913-1919 & 35 \\
\hline & Belgium & $1916-1918$ & 30 \\
\hline & Denmark & $1914-1918$ & 16 \\
\hline & Finland & $1913-1918$ & 35 \\
\hline & France & 1916-1918 & 31 \\
\hline & Germany & 1913-1919 & 29 \\
\hline & Netherlands & $1913-1918$ & 17 \\
\hline & Sweden & $1913-1918$ & 18 \\
\hline \multirow[t]{8}{*}{ Great Depression } & Australia & $1928-1931$ & 20 \\
\hline & Austria & 1929-1933 & 23 \\
\hline & Canada & 1929-1933 & 33 \\
\hline & France & 1929-1932 & 16 \\
\hline & Germany & 1928-1932 & 18 \\
\hline & Netherlands & 1929-1934 & 16 \\
\hline & New Zealand & 1929-1932 & 18 \\
\hline & United States & 1929-1933 & 31 \\
\hline \multirow[t]{2}{*}{ Spanish Civil War } & Portugal & $1934-1936$ & 15 \\
\hline & Spain & $1935-1938$ & 31 \\
\hline \multirow[t]{10}{*}{ World War II } & Austria & $1944-1945$ & 58 \\
\hline & Belgium & 1939-1943 & 24 \\
\hline & Denmark & $1939-1941$ & 24 \\
\hline & France & 1939-1944 & 49 \\
\hline & Germany & 1944-1946 & 64 \\
\hline & Greece & 1939-1945 & 64 \\
\hline & Italy & $1940-1945$ & 45 \\
\hline & Japan & $1943-1945$ & 52 \\
\hline & Netherlands & 1939-1945 & 52 \\
\hline & Norway & 1939-1944 & 20 \\
\hline \multirow[t]{5}{*}{ Aftermaths of wars } & Canada & $1917-1921$ & 30 \\
\hline & Italy & $1918-1921$ & 25 \\
\hline & United Kingdom & $1918-1921$ & 19 \\
\hline & United Kingdom & $1943-1947$ & 15 \\
\hline & United States & $1944-1947$ & 28 \\
\hline
\end{tabular}

Part B: Eight Latin American and Seven Asian Countries in Maddison [2003]

World War I

$\begin{array}{lll}\text { Argentina } & 1912-1917 & 29 \\ \text { Chile } & 1912-1915 & 16 \\ \text { Chile } & 1917-1919 & 23 \\ \text { Uruguay } & 1912-1915 & 30 \\ \text { Venezuela } & 1913-1916 & 17\end{array}$


TABLE I

(CONTINUED)

\begin{tabular}{|c|c|c|c|}
\hline Event & Country & Years & $\begin{array}{l}\% \text { fall in real } \\
\text { per capita } \\
\text { GDP }\end{array}$ \\
\hline \multirow{8}{*}{ Great Depression } & Argentina & 1929-1932 & 19 \\
\hline & Chile & 1929-1932 & 33 \\
\hline & Mexico & 1926-1932 & 31 \\
\hline & Peru & 1929-1932 & 29 \\
\hline & Uruguay & 1930-1933 & 36 \\
\hline & Venezuela & 1929-1932 & 24 \\
\hline & Malaysia & 1929-1932 & 17 \\
\hline & Sri Lanka & 1929-1932 & 15 \\
\hline \multirow[t]{8}{*}{ World War II } & Peru & 1941-1943 & 18 \\
\hline & Venezuela & 1939-1942 & 22 \\
\hline & Indonesia* & $1941-1949$ & 36 \\
\hline & Malaysia** $^{* *}$ & $1942-1947$ & 36 \\
\hline & Philippines*** & $1940-1946$ & 59 \\
\hline & South Korea & $1938-1945$ & 59 \\
\hline & Sri Lanka & $1943-1946$ & 21 \\
\hline & Taiwan & $1942-1945$ & 51 \\
\hline \multirow[t]{11}{*}{ Post-WWII Depressions } & Argentina & $1979-1985$ & 17 \\
\hline & Argentina & 1998-2002 & 21 \\
\hline & Chile & 1971-1975 & 24 \\
\hline & Chile & 1981-1983 & 18 \\
\hline & Peru & 1981-1983 & 17 \\
\hline & Peru & 1987-1992 & 30 \\
\hline & Uruguay & 1981-1984 & 17 \\
\hline & Uruguay & 1998-2002 & 20 \\
\hline & Venezuela & 1977-1985 & 24 \\
\hline & Indonesia & 1997-1999 & 15 \\
\hline & Philippines & $1982-1985$ & 18 \\
\hline \multicolumn{3}{|c|}{ Mean for 60 contractions (excluding 5 war aftermaths in part A) } & 29 \\
\hline
\end{tabular}

Part A uses data from Maddison [2003] for twenty OECD countries for 1900-2000: Australia, Austria, Belgium, Canada, Denmark, Finland, France, Germany, Greece, Italy, Japan, Netherlands, New Zealand, Norway, Portugal, Spain, Sweden, Switzerland, United Kingdom, and United States. Switzerland (-11 percent in 1915-1918 and -10 percent in 1929-1932) had no 15 percent events. With the war aftermaths excluded, the United Kingdom also lacked 15 percent events, and the largest contraction was 7 percent in 1929-1931. Satisfactory data for Ireland are unavailable until after World War II. Data for Greece are missing around World War I, 1914-1920, and also for 1901-1912.

Part B covers eight Latin American and seven Asian countries that have nearly continuous data from Maddison [2003] at least from before World War I. The sample is Argentina, Brazil, Chile, Colombia, Mexico, Peru, Uruguay, Venezuela, India, Indonesia, Malaysia, Philippines, South Korea, Sri Lanka, and Taiwan Data for Argentina and Uruguay after 2001 are from Economist Intelligence Unit, Country Data. Countries that had no 15 percent events are Brazil ( -13 percent in 1928-1931, -13 percent in 1980-1983), Colombia (-9 percent in 1913-1915), and India (-11 percent in 1916-1920, - 12 percent in 1943-1948). Data for Peru appear to be unreliable before the mid-1920s.

Adjustments were made by Maddison to account for changes in country borders.

* No data available for $1942-1948$.

** No data available for 1941-1945.

**** No data available for $1943-1946$. 
with World War II, eight with World War I, eight with the Great Depression, and one or two with the Spanish Civil War. ${ }^{4}$ There are also five aftermaths of wars-three after World War I and two after World War II. However, these experiences involved demobilizations with substantial declines in government purchases and - with the possible exception of Canada after World War I-did not feature decreases in real consumer expenditure. ${ }^{5}$ Therefore, I exclude the war aftermaths from the subsequent analysis.

Although 15 percent or greater declines in real per capita GDP are rare, only Switzerland among the twenty OECD countries lacked any such events in the twentieth century (see the notes to Table I). ${ }^{6}$ The striking observation from part A of Table $\mathrm{I}$ is the dramatic decreases in per capita GDP during the major wars and the Great Depression. In addition, the sharp expansions of government purchases during the wars suggest that consumption fell proportionately by more than GDP (although investment likely declined sharply and net imports may have increased in some cases).

Part B of Table I shows declines of 15 percent or more in real per capita GDP for fifteen additional countries-eight in Latin America and seven in Asia-that have nearly continuous data from Maddison [2003] back at least before World War I. These countries had eleven sharp economic contractions in the postWorld War II period, eight during the Great Depression, eight in World War II, and five around World War I. ${ }^{7}$ Of the fifteen

4. I am unsure whether the fall in real per capita GDP in Portugal by 9 percent in 1935-1936 reflected spillovers from the Spanish Civil War. Per capita GDP happened also to decline by 6 percent in Portugal in 1934-1935.

5. For the United States, data from the Bureau of Economic Analysis show that real consumer expenditure did not decline from 1944 to 1947. The same holds for real consumer expenditure from 1918 to 1921 and 1943 to 1947 in the United Kingdom (see Feinstein [1972]) and for 1918-1921 in Italy (see Rossi, Sorgato, and Toniolo [1993]). Long-term national-accounts data for Canada from Urquhart [1993] do not break down GDP into expenditure components. However, my estimate from Urquhart's data is that real consumer expenditure per person fell by about 18 percent from 1917 to 1921, compared with the decline by 30 percent in real GDP per person in Table I.

6 . With the war aftermaths excluded, the United Kingdom also lacked a 15 percent event.

7. Data are available for a few additional countries starting in the 1920 s and for many countries after World War II. In terms of 15 percent events, this extension adds 6 cases associated with the Great Depression (Costa Rica, Cuba, El Salvador, Guatemala, Honduras, and Nicaragua), 4 during World War II (Costa Rica, Guatemala, Burma, and China), 1 aftermath of World War II (Paraguay), and 30 post-World War II depressions (about half war related) outside of subSaharan Africa. Among all of these additional cases, the largest contractions were 
countries considered, three lacked 15 percent events (see the notes to the table).

Figure I, panel A, uses the information from Table I to plot the size distribution of contractions in the range from 15-19 percent to 60-64 percent. There are 60 events for the 35 countries over 100 years. Thus, the probability of entering into a 15 percent or greater event was 1.7 percent per year. For contractions of 30 percent or more, the number was 24 , and for 45 percent or more, the number was $10 .{ }^{8}$

For some purposes, it is appropriate to adjust the economic contractions for trend growth. Table I, part B, shows the distribution of the adjusted numbers, based on a trend growth rate for real per capita GDP of 2.5 percent per year. As an example, a contraction by 35 percent over five years corresponds to a contraction relative to trend by 43 percent. The mean of the adjusted contraction sizes is 0.35 , compared with 0.29 for the raw numbers.

The lower bound of 15 percent for large contractions is arbitrary. For example, the 35 countries considered in Table I had an additional 21 cases of contraction in the range from 10 percent to 14 percent. ${ }^{9}$ However, the inclusion of these smaller contractions turns out to have a minor effect on the model's predictions for rates of return.

Table II reports realized real rates of return on stocks and bills during the contractions shown in Table I. Stock returns are computed from total-return indexes, except that the values

75 percent for Iraq (1987-1991), 46 percent for Burma (1938-1950), 45 percent for Iran (1976-1981), and 44 percent for West Bank/Gaza (1999-2003). There were also 25 declines of 15 percent or more in real per capita GDP in the 1990s for transitions of former Communist countries.

8. Since worldwide disturbances are the important force in the model, a different way to count is to consider only the three global shocks-World War I, the Great Depression, and World War II. The twentieth century frequency of entering into this kind of global disturbance was 3 percent per year. The size of each global shock would be a weighted average of the declines in per capita GDP shown in Table I along with the smaller decreases for the roughly one-half of countries that did not experience 15 percent events at these times.

9. The list is Australia 11 percent in 1913-1918 and 14 percent in 1943-1946, Belgium 10 percent in 1928-1932, Brazil 13 percent in 1928-1931 and 13 percent in 1980-1983, Finland 10 percent in 1938-1940 and 12 percent in 1989-1993, India 11 percent in 1916-1920 and 12 percent in 1943-1948, Indonesia 14 percent in 1929-1934, New Zealand 11 percent in 1907-1909 and 12 percent in 19471948, Norway 14 percent in 1916-1918, Philippines 12 percent in 1913-1915, Portugal 11 percent in 1927-1928, Switzerland 11 percent in 1915-1918 and 10 percent in 1929-1932, Taiwan 12 percent in 1928-1931, Uruguay 10 percent in 1941-1943 and 10 percent in 1958-1959, and Venezuela 11 percent in 1986-1989. 


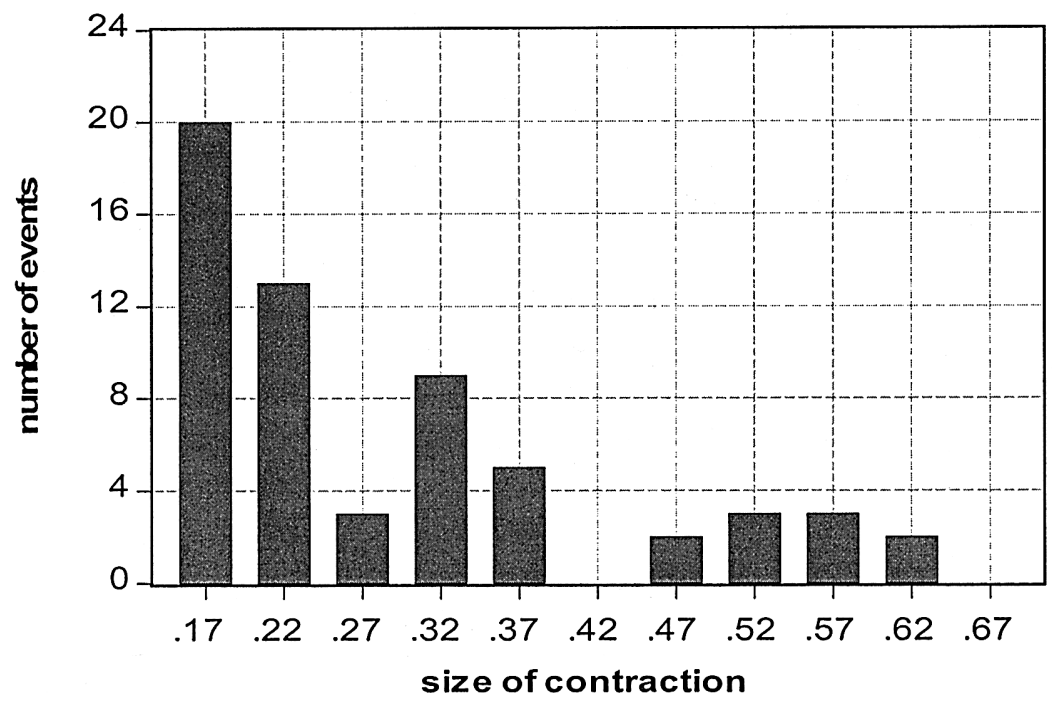

Panel A: Contractions in Table I

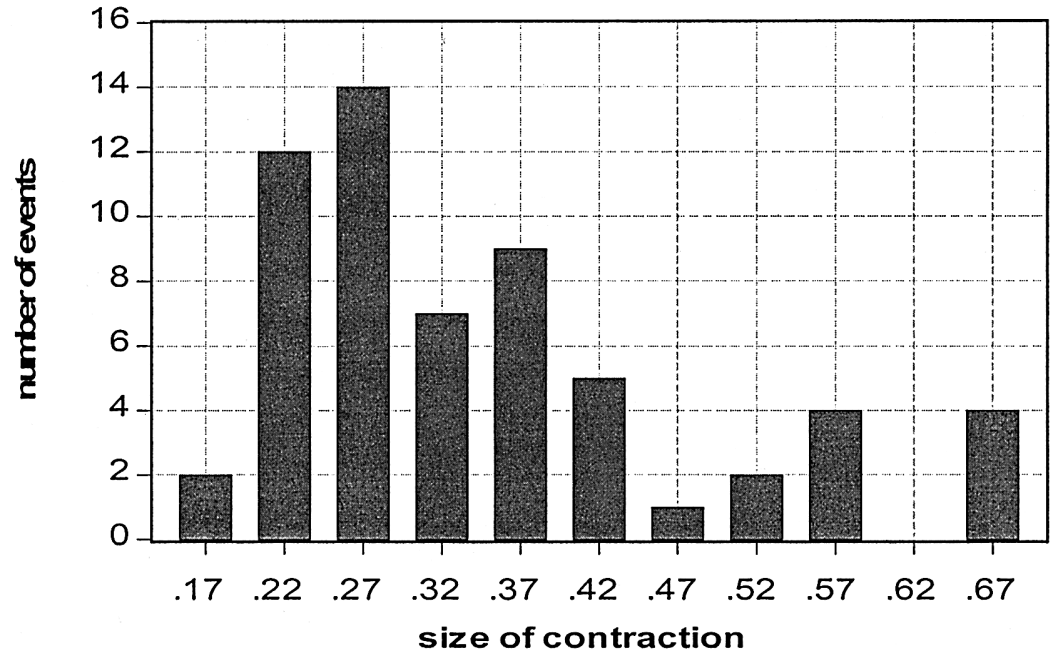

Panel B: Contractions in Table I adjusted for trend growth

Figure I

Frequency Distribution of Economic Disasters

The histograms apply to the 35 countries covered over the twentieth century in Table I. The horizontal axis has intervals for declines in real per capita GDP. The vertical axis shows the number of economic contractions in each interval. The five war aftermaths shown in Table I are excluded; therefore, 60 events are used. The bottom panel adjusts for trend growth at 0.0252 per year. 
TABLE II

Stock ANd Bill Returns DURING ECONOMic CRISES

\begin{tabular}{|c|c|c|}
\hline Event & $\begin{array}{l}\text { Real stock return } \\
\quad(\% \text { per year })\end{array}$ & $\begin{array}{l}\text { Real bill return } \\
(\% \text { per year })\end{array}$ \\
\hline \multicolumn{3}{|l|}{ World War I } \\
\hline Austria, 1914-1918 & - & -4.1 \\
\hline Denmark, 1914-1918 & - & -6.9 \\
\hline France, 1914-1918 & -5.7 & -9.3 \\
\hline Germany, 1914-1918 & -26.4 & -15.6 \\
\hline Netherlands, 1914-1918 & - & -5.2 \\
\hline Sweden, 1914-1918 & $-15.9^{*}$ & -13.1 \\
\hline \multicolumn{3}{|l|}{ Great Depression } \\
\hline Australia, 1928-1930 & -3.6 & 8.2 \\
\hline Austria, 1929-1932 & $-17.3^{*}$ & 7.1 \\
\hline Canada, 1929-1932 & $-23.1^{*}$ & 7.1 \\
\hline Chile, 1929-1931 & $-22.3^{*}$ & - \\
\hline France, 1929-1931 & -20.5 & 1.4 \\
\hline Germany, 1928-1931 & -14.8 & 9.3 \\
\hline Netherlands, 1929-1933 & $-14.2^{*}$ & 5.7 \\
\hline New Zealand, 1929-1931 & $-5.6^{*}$ & 11.9 \\
\hline United States, 1929-1932 & -16.5 & 9.3 \\
\hline \multicolumn{3}{|l|}{ Spanish Civil War } \\
\hline Portugal, 1934-1936 & $13.4^{*}$ & 3.8 \\
\hline \multicolumn{3}{|l|}{ World War II } \\
\hline Denmark, 1939-1945 & $-3.7^{*}$ & -2.2 \\
\hline France, 1943-1945 & -29.3 & -22.1 \\
\hline Italy, 1943-1945 & -33.9 & -52.6 \\
\hline Japan, 1939-1945 & -2.3 & -8.7 \\
\hline Norway, 1939-1945 & $1.7^{*}$ & -4.5 \\
\hline \multicolumn{3}{|l|}{ Post-WWII Depressions } \\
\hline Argentina, 1998-2001 & -3.6 & 9.0 \\
\hline Chile, 1981-1982 & $-37.0^{*}$ & 14.0 \\
\hline Indonesia, 1997-1998 & -44.5 & 9.6 \\
\hline Philippines, 1982-1984 & -24.3 & -5.0 \\
\hline Thailand, 1996-1997** & -48.9 & 6.0 \\
\hline Venezuela, 1976-1984 & $-8.6^{*}$ & - \\
\hline
\end{tabular}

Real rates of return on stocks and bills are for periods corresponding to the economic contractions in Table I. For the Great Depression and post-World War II depressions, the periods are from the start of the depression to the year before the rebound in the economy. For the world wars, the periods are 1914-1918 and 1939-1945, except for France and Italy where data for 1939-1942 are problematic. The returns are averages of arithmetic annual real rates of return based on total-return indexes, except the entries marked by an asterisk used stock-price indexes. Real values were computed by using consumer price indexes. Data are from Global Financial Data, except that the nominal return on bills for Indonesia in 1997-1998 is for moneymarket rates from EIU Country Data.

* Based on stock-price indexes, rather than total-return indexes.

** Thailand's contraction of real per capita GDP by 14 percent for 1996-1998 falls just short of the 15 percent criterion used in Table I. 
marked by an asterisk come from stock-price indexes (and, therefore, neglect dividends). The bills data are usually for short-term government bills but sometimes for money-market instruments or certificates of deposit. Real values were computed by using consumer price indexes. Out of the 60 cases in Table I (not counting the 5 war aftermaths), full data on asset returns are available for 21 cases. Information also appears in Table II for 1996-1997 for Thailand, which was not included in Table I. Another five cases in Table II have returns for stocks or bills but not both.

For the Great Depression I measured returns up to the year before the rebound in the economy. The average real rate of return was -15.3 percent per year for stocks (nine cases) and 7.5 percent per year for bills (eight cases). Thus, stocks did badly, and bills did well.

For the post-World War II depressions in part B of Table I, I again calculate returns up to the year before the rebound in the economy. The average real rate of return was -27.8 percent per year for stocks (six cases) and 6.7 percent per year for bills (five cases). ${ }^{10}$ Thus, again, stocks did badly, and bills did comparatively well.

For the world wars, the returns shown in Table II are for the war periods, 1914-1918 and 1939-1945, except where data are unreliable (France and Italy for 1939-1942). In World War I, average real returns were -16.0 percent per year for stocks (three cases) and -9.0 percent per year for bills (six cases). ${ }^{11} \mathrm{In}$ World War II, averages for five cases were -13.5 percent per year for stocks and -18.0 percent per year for bills. Overall, the wartime pattern is that real rates of return were sharply negative on both forms of assets, and no clear pattern of relative performance emerges. These conclusions still hold if the intervals for returns are aligned more closely to the times of economic contraction, rather than the full war periods.

Finally, in Portugal during the Spanish Civil War, real re-

10. Partial default on Argentine government bonds occurred after the end date, 2001, used in Table II. For 1998-2002, the average real rates of return were -3.7 percent per year for stocks and -0.1 percent per year for bills.

11. The impact of the German hyperinflation came in 1920-1923, after the end date, 1918, used in Table II. For 1920-1922, the average annual real rate of return on German stocks was -50.7 percent, while that on bills was -56.2 percent. Thus, surprisingly, stocks did almost as badly in real terms as bills. The data for 1923, the peak year of the hyperinflation, are unreliable, though stocks clearly did far better in real terms than in 1922. 
turns were 13.4 percent per year on stocks and 3.8 percent per year on bills. Thus, although this noncombatant country had a significant economic contraction (Table I), the asset returns were not low.

The overall conclusion is that government bills outperformed stocks in most economic crises unrelated to war-represented by the Great Depression and post-World War II depressions in Latin America and Asia. However, bills were not systematically better or worse than stocks during economic contractions related to major wars. ${ }^{12}$

\section{I.C. Default Probability}

The disaster shock $v_{t}$ can account for the behavior of stock returns during economic contractions of the sort considered in Table I. However, the low returns on government bills during some wartime contractions depend on another factor, akin to partial default or loss of property rights. Outright default on government paper does not typify the twenty OECD economies considered in part A of the table-which notably omits Czarist Russia and the American Confederacy. ${ }^{13}$ For example, France did not default after World War II on debts incurred by the Third Republic or the Vichy government, and Belgium and the Netherlands did not explicitly default after World War II on government bonds but did have forced conversions into illiquid instruments. The most common mechanism for partial default was depreciation of the real value of nominal debt through high inflation, which occurred during and shortly after some wartime experiences. ${ }^{14}$

Default probability can be introduced in a number of ways. I make the following assumptions. First, default never occurs in normal times but occurs with a constant probability $q \geq 0$ when a $v$-type disaster occurs. (The probability $q$ is a pure number,

12. Better performing assets in these circumstances would be precious commodities, such as gold and diamonds, and maybe Swiss bank accounts and human capital.

13. The Bolshevik government repudiated Russian government bonds in 1918, and the U. S. government repudiated Confederate bonds in the Fourteenth Amendment, ratified in 1868.

14. Notable are the hyperinflations in the early 1920s in Germany and Austria, likely due to Reparations payments imposed after World War I, rather than the war directly. High inflation also occurred during and after World War I in France and during or after World War II in Austria, Belgium, Finland, France, Greece, Italy, and Japan. In West Germany, suppressed inflation associated with World War II was effectively ratified by a 10:1 currency conversion and the lifting of price controls in 1948. 
whereas the probability $p$ is per unit of time.) Second, when a default occurs, the fraction $d$ of the gross return on bills is wiped out. Third, default never applies to equities. ${ }^{15}$ Fourth, default does not affect productivity, $A_{t+1}$, and, hence, real GDP. The proceeds from default are returned as lump-sum transfers to the representative consumer. Given these assumptions, the gross return $R_{t 1}^{b}$ on government bills is as follows:

probability $e^{-p}: R_{t 1}^{b}=$ the specified face amount, $R_{t 1}^{f}$,

probability $1-e^{-p}$ : probability $1-q: R_{t 1}^{b}$

$$
=R_{t 1}^{f} \text {, probability } q: R_{t 1}^{b}=(1-d) \cdot R_{t 1}^{b} .
$$

\section{I.D. Calibration of Disaster Parameters}

Economic disasters are characterized by four objects: the probability of disaster, $p$ per year, the size of contraction, $b$, the probability of default (contingent on the occurrence of disaster), $q$, and the extent of default, $d$. I use the historical patterns from Tables I and II and Figure I to generate reasonable values for these objects.

The frequency of disasters (60 occurrences for 35 countries over 100 years) implies a baseline value for $p$ of 1.7 percent per year. The contraction sizes, $b$, from Table I and Figure I indicate a range of 15 percent to 64 percent. I use the empirical frequency distribution in Figure I, panel A, to calibrate the model for $b$. (In a later analysis I use the distribution for the trend-adjusted values shown in panel B.) I assume that, contingent on a disaster, the probability distribution for $b$ is the same at all points in time. The mean of the proportionate contractions shown in Figure I, panel $\mathrm{A}$, is 0.29 . However, the empirical counterpart of $b$ is not the mean. Because of diminishing marginal utility of consumption, larger contractions count more than smaller ones; hence, the effective average value of $b$ exceeds 0.29 .

Table II suggests that some form of partial default on government bills (typically through inflation) is likely during eco-

15. In some circumstances, particularly involving wars and changes of government, property rights on equity shares can be threatened. One example, not included in the data set, is the Russian Revolution of 1917. Another case involves the German hyperinflation, where the real value of stocks declined sharply through 1922. Bresciani-Turroni [1937, p. 265] observed that the capitalized value of Daimler Motors fell to the equivalent of 327 cars. Explanations that have been offered include potential future corporate liability for reparations payments and the possible loss of ownership rights due to the introduction of Communism. 
nomic contractions associated with major war. However, default is less likely for wartime contractions in which the country was not directly involved in the conflict. Experiences of this type in Table I are Portugal during the Spanish Civil War and Latin America during World Wars I and II. Based on this reasoning, 25 of the 60 events (42 percent) shown in Table I featured partial default on bills. Thus, a reasonable number for $q$, the conditional default probability on bills, is 0.4 .

Table II shows that, during major wartime contractions, average real returns on bills were similar to those on stocks. To get this pattern in the model, the size of partial default, $d$, has to be close to the size of economic contraction, $b$. Therefore, I assume that $d=b$ in the calibration exercises.

\section{I.E. Solution of the Model}

Given the process for $A_{t+1}$ in (7) and the assumed distributions for $u_{t+1}$ and $v_{t+1},(6)$ determines the price of the one-period equity claim. The result is

$$
P_{t 1}=A_{t} e^{-\rho-(\theta-1) \gamma+(1 / 2)(\theta-1)^{2} \sigma^{2}} \cdot\left[e^{-p}+\left(1-e^{-p}\right) \cdot E(1-b)^{(1-\theta)}\right],
$$

where $E$ denotes the expectation operator.

The expected gross return on one-period equity is $E_{t}\left(R_{t 1}^{e}\right)=$ $E_{t}\left(A_{t+1}\right) / P_{t 1}$. I focus on the expected rate of return that applies asymptotically as the arbitrary period length approaches zero. The result is

$$
\begin{aligned}
\log \left[E_{t}\left(R_{t 1}^{e}\right)\right]=\rho+\theta \gamma-(1 / 2) \theta^{2} \sigma^{2} & +\theta \sigma^{2} \\
& -p \cdot\left[E(1-b)^{1-\theta}-1+E b\right] .
\end{aligned}
$$

For a sample conditioned on no disasters, the expected rate of return is higher by $p \cdot E b$ :

$$
\begin{aligned}
\log \left[E_{t}\left(R_{t 1}^{e}\right)\right]_{v_{t+1}=0}=\rho+\theta \gamma-(1 / 2) \theta^{2} \sigma^{2} & +\theta \sigma^{2} \\
& -p \cdot\left[E(1-b)^{(1-\theta)}-1\right] .
\end{aligned}
$$

The face rate of return on government bills, $R_{t 1}^{f}$, can be determined from (4). As the period length approaches zero, this rate of return is

$$
\begin{array}{r}
\log \left(R_{t 1}^{f}\right)=\rho+\theta \gamma-(1 / 2) \theta^{2} \sigma^{2}-p \cdot\left[(1-q) \cdot E(1-b)^{-\theta}\right. \\
\left.+q \cdot E(1-b)^{1-\theta}-1\right] .
\end{array}
$$

Note that the derivation of (11) assumes that the default size $d$ 
equals the size of economic contraction $b .{ }^{16}$ The full expected rate of return on bills, which includes the default possibility, is lower by $p q \cdot E b$ :

$$
\begin{aligned}
\log \left[E_{t}\left(R_{t 1}^{b}\right)\right]=\rho+\theta \gamma-(1 / 2) \theta^{2} \sigma^{2}-p \cdot\left[(1-q) \cdot E(1-b)^{-\theta}\right. & \\
& \left.+q \cdot E(1-b)^{1-\theta}+q \cdot E b-1\right] .
\end{aligned}
$$

The $\rho+\theta \gamma$ part of the rates of return in (9)-(12) corresponds to the steady-state real interest rate in the deterministic neoclassical growth model $(\sigma=p=0)$. The equity premium, log $\left[E_{t}\left(R_{t 1}^{e}\right)\right]-\log \left[E_{t}\left(R_{t 1}^{b}\right)\right]$, is given from (9) and (12) by

$$
\begin{aligned}
\text { equity premium }=\theta \sigma^{2}+p \cdot & (1-q) \\
\cdot & {\left[E(1-b)^{-\vartheta}-E(1-b)^{1-\theta}-E b\right] . }
\end{aligned}
$$

For a sample conditioned on no disasters (and, therefore, also no defaults), the premium can be calculated from (10) and (11) as

$$
\begin{aligned}
\text { equity premium }_{\mid v_{t+1}=0}=\theta \sigma^{2}+p \cdot & (1-q) \\
\cdot & {\left[E(1-b)^{-\theta}-E(1-b)^{1-\theta}\right] . }
\end{aligned}
$$

The equity premiums in (13) and (14) are increasing in $p$ and $\theta$ and decreasing in $q$. The premiums are also higher if the distribution of $b$ shifts toward larger values.

Because $u_{t}$ and $v_{t}$ are i.i.d., the results take the same form for longer term claims. The price of an equity claim that pays $A_{t+2}$ in period $t+2$ looks like (8), except that the expression in the first brackets is multiplied by two, and the expression in the second brackets enters as a square. The expected rate of return on this two-period claim (and on claims further into the future) is still given by (9) and (10). Similarly, rates of return on bills that pay out in periods $t+2, \ldots$, are still given by (11) and (12). That is, with the i.i.d. specification, the term structure of interest rates is flat. ${ }^{17}$

An equity share on a tree is a claim on the stream of "dividends," $A_{t+1}, A_{t+2}, \ldots$ The price of this asset equals the sum of the prices of the claims on each period's dividend (output). Defining

16. The probability of default, $q$, is assumed to be independent of $b$. However, the pricing formula depends on $q d$. Therefore, the results would be the same if $d$ were fixed but $q$ rose in proportion to $b$.

17. The assumption is that a two-period bill has two chances of default in proportionate size $d$. Each chance is with probability $q$ contingent on the occurrence of a disaster in period $t+1$ or $t+2$. 


$$
\Phi \equiv e^{-\rho-(\theta-1) \gamma+(1 / 2)(\theta-1)^{2} \sigma^{2}} \cdot\left[e^{-p}+\left(1-e^{-p}\right) \cdot E(1-b)^{(1-\theta)}\right],
$$

which appears in (8), the formula for the share price is

$$
P_{t}=A_{t} \cdot \Phi /(1-\Phi),
$$

so that the "price-earnings ratio" $P_{t} / A_{t}$ is

$$
P_{t} / A_{t}=\Phi /(1-\Phi) \text {. }
$$

As the period length approaches zero, the P-E ratio approaches ${ }^{18}$

$$
\frac{P_{t}}{A_{t}}=\frac{1}{\rho+(\theta-1) \gamma-(1 / 2)(\theta-1)^{2} \sigma^{2}-p \cdot\left[E(1-b)^{(1-\theta)}-1\right]} .
$$

The model also determines the expected growth rate of the economy. Using (7) and allowing the period length to approach zero, the expected growth rate is

$$
\log \left[\left(E_{t} A_{t+1}\right) / A_{t}\right]=\gamma+(1 / 2) \sigma^{2}-p \cdot E b .
$$

Thus, the expected growth rate is decreasing in $p$ and $E b$. For a sample conditioned on no disasters, the expected growth rate is higher by $p \cdot E b$ :

$$
\log \left[\left(E_{t} A_{t+1}\right) / A_{t}\right]_{\mid v_{t+1}=0}=\gamma+(1 / 2) \sigma^{2},
$$

which is independent of $p$ and $E b$.

\section{I.F. Calibration of Other Parameters}

The remaining parameters to specify are $\gamma, \sigma, \rho$, and $\theta$. The values of $\gamma$ and $\sigma$ determine the mean and standard deviation of the growth rate of output and consumption in no-disaster periods. For annual U. S. data from 1890 to $2004,{ }^{19}$ the growth rate of real consumer expenditure per person has a mean of 0.020 and a standard deviation of 0.035 . For real per capita GDP, the values are 0.021 and 0.045 . For 1954-2004, the means are similar, but the standard deviations are smaller: the growth rate of real per capita consumer expenditure has a mean of 0.024 and a standard

18. Equation (16) is valid if $\Phi<1$, which guarantees that expected utility is finite (see Kocherlakota [1990]). When $\sigma=p=0, \Phi<1$ corresponds to the familiar transversality condition, $\rho+\theta \gamma>\gamma$ - the real interest rate exceeds the growth rate. The condition $\Phi<1$ in the stochastic context corresponds to log $\left[E_{t}\left(R_{t 1}^{e}\right)\right]>\log \left(E_{t} A_{t+1} / A_{t}\right)$. From (17), the condition is $\rho+(\theta-1) \gamma-(1 / 2)(\theta-$ 1) ${ }^{2} \sigma^{2}-p \cdot\left[E(1-b)^{(1-\theta)}-1\right]>0$.

19. National-accounts data since 1929 are from the Bureau of Economic Analysis. Earlier data are from Kendrick [1961] and Romer [1988, 1989]. 
TABLE III

Growth Rates of Real Per Capita GDP in G7 Countries

\begin{tabular}{lcccccccc}
\hline \hline & \multicolumn{6}{c}{ Growth rate of real per capita GDP, 1890-2004 } \\
\cline { 2 - 7 } & Canada & France & Germany* & Italy & Japan & U. K. & U. S. \\
\hline Mean & 0.021 & 0.020 & 0.019 & 0.022 & 0.027 & 0.015 & 0.021 \\
Standard deviation & 0.051 & 0.069 & 0.090 & 0.059 & 0.082 & 0.030 & 0.045 \\
Kurtosis & 5.4 & 5.4 & 40.6 & 10.4 & 49.0 & 5.8 & 5.8 \\
& \multicolumn{7}{c}{ Growth rate of real per capita } & GDP, 1954-2004 \\
Mean & 0.022 & 0.026 & 0.027 & 0.030 & 0.043 & 0.021 & 0.021 \\
Standard deviation & 0.023 & 0.017 & 0.024 & 0.022 & 0.034 & 0.018 & 0.022 \\
Kurtosis & 3.4 & 2.5 & 3.9 & 2.8 & 2.4 & 3.1 & 2.6 \\
\hline \hline
\end{tabular}

* Data missing for Germany in 1918-1919.

Except for the United States, data are from Maddison [2003], updated through 2004 using information from Economist Intelligence Unit, Country Data. The U. S. sources are noted in the text.

deviation of 0.017 , whereas the values for per capita GDP are 0.021 and 0.022 . To some extent, the higher volatility before World War I may reflect poorer data (see Romer [1988, 1989]).

Table III shows statistics for growth rates of real per capita GDP for the G7 countries for 1890-2004 and 1954-2004. Standard deviations for 1954-2004 are similar to that for the United States, ranging between 0.02 and 0.03 . Values for the longer samples are higher, reflecting the events in Table I and probably to a minor extent the lower quality of earlier data. Mean growth rates of per capita GDP for 1954-2004 are 0.02-0.03, except for Japan, which has 0.04 . For 1890-2004, mean growth rates range from 0.015 for the United Kingdom to 0.027 for Japan.

Table III also shows the sample kurtosis for growth rates. For 1954-2004, the numbers are close to three, the value for a normal density. Standard tests, such as Anderson-Darling, accept the hypothesis of normality with $p$-values above 0.05 . Hence, for this tranquil period-in which the G7 countries avoided major crises-the growth-rate data seem reasonably described as normal. The situation is different for 1890-2004, where the kurtosis always exceeds five and reaches astronomical levels for Germany and Japan. ${ }^{20}$ These high values-indications of fat tails-reflect

20. In the model, the kurtosis can be expressed as a function of $p, b$, and $\sigma$. The kurtosis equals 3 when $p=0$ but is very sensitive to $p$. For example, with a fixed value $b=0.5$, the kurtosis peaks at 156 when $p=0.0016$ and then falls to 74 when $p=0.01$ and 43 when $p=0.02$. 
the kinds of disasters shown in Table I, especially during World War II. Standard tests, including Anderson-Darling, reject normality at low $p$-values. That is, normality does not accord with samples such as 1890-2004 that include occurrences of disasters. ${ }^{21}$

Based on Table III for the 1954-2004 samples, I calibrate the model with $\gamma=0.025$ and $\sigma=0.02$. The parameter $\gamma$ does not affect the equity premium in (13) but does affect levels of rates of return and the price-earnings ratio. The parameter $\sigma$ affects the equity premium but is quantitatively unimportant in the relevant range.

The rate of time preference, $\rho$, does not affect the equity premium in (13) but does affect levels of rates of return and the price-earnings ratio. In the baseline specification, I assume that $\rho=0.03$ per year, a value often used in the saving literature, such as Hubbard, Skinner, and Zeldes [1995].

The coefficient of relative risk aversion, $\theta$, matters more for the results. The usual view in the finance literature is that $\theta$ is in the range of something like 2 to 5 . From the standpoint of intertemporal substitution of consumption, Barro and Sala-i-Martin [2004, Ch. 2] argue that a similar range for $\theta$ is needed to accord with country-level observations on levels and transitional behavior of saving rates. ${ }^{22}$ If $\theta$ is much below 2, saving rates fall markedly as a country develops. If $\theta$ is much above 4, levels of saving rates are counterfactually low. In the calibrations, I use $\theta$ equal to 3 or 4 .

\section{Replication of Mehra and Prescott}

To see what the model is trying to fit, Table IV shows average real rates of return on stocks and bills for the G7 countries. Part

21. With respect to skewness, negative values apply to six of the seven countries for 1890-2004. The magnitudes are particularly large for Germany and Japan ( -5.2 and -5.6 , respectively), and the skewness is positive only for France (0.5, because of a dramatic rise in per capita GDP in 1946). For 1954-2004, skewness is negative for four countries and positive for three countries.

22 . In the present model, the coefficient of relative risk aversion, $\theta$, equals the reciprocal of the intertemporal elasticity of substitution for consumption. My view is that this restriction may be satisfactory for studying asset pricing and economic growth. Kocherlakota [1990] uses the framework of Epstein and Zin [1989] to explore an asset-pricing model in which the two forces can be distinguished. 
TABLE IV

STOCK AND BiLl RETURNS For G7 COUNTRIES

(Averages of Arithmetic Annual Returns, Standard Deviations in PAREnTHeses)

\begin{tabular}{lccc}
\hline \hline Country \& time period & $\begin{array}{c}\text { Real stock } \\
\text { return }\end{array}$ & $\begin{array}{c}\text { Real bill } \\
\text { return }\end{array}$ & Spread \\
\hline 1. Long samples & & & \\
Canada, 1934-2004 & $0.074(0.160)$ & $0.010(0.036)$ & $0.063(0.163)$ \\
France, 1896-2004 & $0.070(0.277)$ & $-0.018(0.095)$ & $0.088(0.279)$ \\
Germany, 1880-2004* & $0.052(0.306)$ & $-0.009(0.142)$ & $0.061(0.269)$ \\
Italy, 1925-2004 & $0.063(0.296)$ & $-0.009(0.128)$ & $0.072(0.283)$ \\
Japan, 1923-2004 & $0.092(0.296)$ & $-0.012(0.138)$ & $0.104(0.271)$ \\
U. K., 1880-2004 & $0.063(0.183)$ & $0.016(0.055)$ & $0.047(0.179)$ \\
U. S., 1880-2004 & $0.081(0.190)$ & $0.015(0.047)$ & $0.066(0.191)$ \\
Means & $0.071(0.240)$ & $-0.001(0.092)$ & $0.072(0.234)$ \\
2. 1954-2004 & & & \\
Canada & $0.074(0.165)$ & $0.024(0.024)$ & $0.050(0.168)$ \\
France & $0.091(0.254)$ & $0.019(0.029)$ & $0.072(0.252)$ \\
Germany & $0.098(0.261)$ & $0.018(0.015)$ & $0.080(0.260)$ \\
Italy & $0.067(0.283)$ & $0.016(0.034)$ & $0.051(0.279)$ \\
Japan & $0.095(0.262)$ & $0.012(0.037)$ & $0.083(0.253)$ \\
U. K. & $0.097(0.242)$ & $0.018(0.033)$ & $0.079(0.250)$ \\
U. S. & $0.089(0.180)$ & $0.014(0.021)$ & $0.076(0.175)$ \\
Means & $0.087(0.235)$ & $0.017(0.028)$ & $0.070(0.234)$ \\
\hline \hline
\end{tabular}

* Data missing for Germany in 1923-1924 and 1945.

Indexes of cumulated total nominal returns on stocks and government bills or analogous paper are from Global Financial Data. See Taylor [2005] for a discussion. Nominal values for December of each year are converted to real values by dividing by consumer price indexes. Annual real returns are computed arithmetically based on December-to-December real values. CPI data since 1970 are available online from Bureau of Labor Statistics and OECD. Earlier data are from Bureau of Labor Statistics, U. S. Department of Commerce [1975], Mitchell [1980, 1982, 1983], and Mitchell and Deane [1962]. The German data for the CPI have breaks corresponding to the hyperinflation in 1923-1924 and the separation into East and West in 1945. Therefore, real returns are unavailable for these years. German data on dividends are missing for 1942-1952. Hence, total stock returns for these years are understated.

1 has long samples back as far as $1880,{ }^{23}$ and part 2 is for 1954-2004. For the long samples, the average real rate of return on stocks is 0.071 , whereas, for $1954-2004$, the average is 0.087 . Average real bill returns are -0.001 for the long samples and 0.017 for $1954-2004$. Thus, the average equity premium is around 0.07 for both samples.

Table V, column (1), shows the model's rates of return and growth rates for the Mehra and Prescott [1985] case, where the

23. Germany has missing data for 1923-1924 and 1945. These lapses reflect the German hyperinflation and World War II. For a discussion of sample-selection problems in the context of stock returns, see Jorion and Goetzmann [1999]. 
disaster probability $p$ is nil. Equation (13) shows that the equity premium is $\theta \sigma^{2}$ when $p=0$. Therefore, when $\theta=4$ and $\sigma=0.02$, the premium is 0.0016 , compared with the observed value of 0.07 . This spectacular failure has been often discussed in the assetpricing literature, summarized in Campbell [2000] and Mehra and Prescott [2003]. The main source of difficulty is that the model's real bill rate is way too high. When $\theta=4$ and $\sigma=0.02$, (11) implies a real bill rate of 0.127 , far above observed values of less than 0.02 in Table IV.

The model cannot be fixed by reasonable modifications of the parameters $\theta$ and $\sigma$. To get an equity premium of 0.07 when $\theta=$ $4, \sigma$ has to be 0.13 , way above observed standard deviations for annual growth rates of real per capita GDP and consumer expenditure. If $\sigma=0.02, \theta$ has to be 175 to get a spread of 0.07 . However, a large $\theta$ does not accord with observed real bill rates. If $\theta \sigma^{2}=0.07$, to get a real bill rate around 0.02 in (11) when $p=$ $0, \theta$ has to be close to 1 . Then, to get the right equity premium, $\sigma$ has to be around 0.26 , even further above observed values.

\section{LEVERAGE}

The results can change when equity shares represent a claim on only a part of GDP and consumption. The equity premium is higher than in the baseline model if the ratio of equity payments to consumption is procyclical, in particular, low in the wake of a disaster. This pattern arises, for example, with leverage-when the ownership structure for trees includes fixed claims (bonds) as well as equities.

I consider again one-period claims, which apply to next period's dividend $A_{t+1}$. Suppose that the capital structure includes equity and one-period private bonds. These bonds are identical to government bills-they promise the gross face return $R_{t 1}^{f}$, but partial default in the proportion $d$ occurs with probability $q$ when a disaster occurs. This specification is reasonable if private bonds are nominally denominated, like most government bills, and if partial default occurs through inflation. I assume that default on private bonds does not occur in the absence of a disaster.

I use the following structure to analyze leverage. At the start of period $t$, a tree owner issues a one-period claim on $A_{t+1}$ that sells at the (equilibrium) price $P_{t 1}$. Then the owner issues $\beta_{t}$ units of one-period private bonds and gives the proceeds to the equity 
holder. ${ }^{24}$ Thus, the net price paid for levered equity is $P_{t 1}-\beta_{t}$. In period $t+1$, output is $A_{t+1}$, and the contractual payment to bondholders is $\beta_{t} \cdot R_{t 1}^{f}$. The proportion $d$ of the bond payment is withheld with probability $q$ if a disaster occurs. The rest of the output goes to the equity holder. I make an assumption so that, as the length of the period shrinks to zero, output is sufficient to cover the debt obligation with probability one.

In accordance with Modigliani-Miller, leverage does not affect the overall market value of claims on next period's output, which is still given by the expression for $P_{t 1}$ in (8). However, the debt issue $\beta_{t}$ affects the expected rate of return on levered equity, which is valued at $P_{t 1}-\beta_{t}$. An expression for the expected rate of return on levered equity can be derived from the pricing formula in (4).

The debt-equity ratio $\lambda$ is given as the length of the period approaches zero by

$$
\lambda=\beta_{t} /\left(A_{t}-\beta_{t}\right) .
$$

I treat $\lambda$ as a constant, constrained to satisfy a condition that rules out bankruptcy:

$$
\lambda<\left(1-b_{\max }\right) / b_{\max },
$$

where $b_{\max }$ is the largest possible value of $b$. When this condition holds, the expected rate of return on levered equity turns out to be

$$
\begin{aligned}
\log \left[E_{t}\left(R_{t 1}^{e}\right)\right]=\rho+\theta \gamma-(1 / 2) \theta^{2} \sigma^{2}+(1+\lambda) & \\
\cdot & \left\{\theta \sigma^{2}-p \cdot\left[E(1-b)^{1-\theta}-1+E b\right]\right\}-p \lambda \\
& \cdot\left[1-q \cdot E b-(1-q) \cdot E(1-b)^{-\theta}-q \cdot E(1-b)^{1-\theta}\right] .
\end{aligned}
$$

This formula generalizes (9) to allow for $\lambda>0$. The levered equity premium is the difference between (22) and the expected bill rate in (12). The result is that the levered equity premium is the multiple $1+\lambda$ of the unlevered premium in (13):

$$
\text { levered equity premium }=(1+\lambda)
$$

$$
\cdot\left\{\theta \sigma^{2}+p \cdot(1-q) \cdot\left[E(1-b)^{-\vartheta}-E(1-b)^{1-\theta}-E b\right]\right\} .
$$

24. Analogously, a two-period equity claim, applying to $A_{t+2}$, could be paired with a two-period bond, which pays off at $t+2$. An equity claim on the tree would be matched with a complete term structure of bonds. With the i.i.d. assumptions that I make, these longer term levered claims would have the same properties as the one-period claim that I analyze. 
According to the Federal Reserve's Flow-of-Funds Accounts, recent debt-equity ratios for the U. S. nonfinancial corporate sector are around 0.5 . If $\lambda \approx 0.5$, leverage does not affect the main conclusions about the equity premium in the model without disasters, $p=0$. If the unlevered spread is trivial-less than 0.002 -multiplying by 1.5 (when $\lambda=0.5$ ) still generates a trivial number. However, when $p>0$, the value of $\lambda$ significantly affects the quantitative results.

The effective leverage coefficient, $\lambda$ in (23), would exceed the debt-equity ratio if there were other reasons for a procyclical pattern of the ratio of equity payments to consumption. One possible source of this pattern is that the ratio of labor income to GDP is countercyclical. Another possibility is that the ratio of consumption to GDP is countercyclical (because the ratio of investment to GDP is procyclical). At present, I do not analyze these mechanisms. However, to get an idea of the potential effects, it may be reasonable to consider values of $\lambda$ that exceed observed debt-ratios of around 0.5 .

\section{Rare Disasters and the Equity Premium}

I now allow for the disaster probability, $p>0$. Results from calibrations of the model are in Table V. I use the parameter values discussed before along with the empirical frequency distribution for disaster sizes, $b$, shown in Figure I, panel A.

The potential for disasters affects the variance of the growth rate, $A_{t+1} / A_{t}$. As the length of the period approaches zero, this variance can be determined from (7) as

$$
\operatorname{VAR}\left(A_{t+1} / A_{t}\right)=\sigma^{2}+p \cdot E\left(b^{2}\right) .
$$

The distribution of disaster sizes in Figure I, panel A, implies $E\left(b^{2}\right)=0.10$. Using the trend-adjusted values in panel B leads to the higher value 0.14 . Using $\sigma=0.02$ and $p=0.017$, the standard deviation of the growth rate in (24) is 0.046 per year with the raw numbers for $b$ and 0.053 for the trend-adjusted numbers. These values are somewhat below the average of 0.061 for the standard deviation of the growth rates of real per capita GDP for the G7 countries for 1890-2004 (Table III). These long samples can be viewed as containing the representative number of $v$-type disasters.

Table V, column (2), which assumes that $\theta=4$, shows that an allowance for rare disasters can generate reasonable equity pre- 
TABLE V

Calibrated Model for Rates of Return

\begin{tabular}{|c|c|c|c|c|c|c|c|}
\hline & (1) & \multicolumn{4}{|c|}{ Parameters } & (6) & (7) \\
\hline & $\begin{array}{c}\text { No } \\
\text { disasters }\end{array}$ & Baseline & $\begin{array}{c}\text { Low } \\
\theta\end{array}$ & $\begin{array}{l}\text { High } \\
p\end{array}$ & $\begin{array}{l}\text { Low } \\
q\end{array}$ & $\begin{array}{c}\text { Low } \\
\gamma\end{array}$ & $\begin{array}{c}\text { Low } \\
\rho\end{array}$ \\
\hline \multicolumn{8}{|l|}{$\theta$ (coeff. of relative risk } \\
\hline $\begin{array}{l}\sigma \text { (s.d. of growth rate, no } \\
\text { disasters) } \\
\rho \text { (rate of time }\end{array}$ & 0.02 & 0.02 & 0.02 & 0.02 & 0.02 & 0.02 & 0.02 \\
\hline & 0.03 & 0.03 & 0.03 & 0.03 & 0.03 & 0.03 & 0.02 \\
\hline deter & 0.025 & 0.025 & 0.025 & 0.025 & 0.025 & 0.020 & 0.025 \\
\hline$p$ (disaster $\mathrm{r}$ & $\mathbf{0}$ & 0.017 & 0.017 & 0.025 & 0.017 & 0.017 & 0.017 \\
\hline $\begin{array}{l}q \text { (bill default probability } \\
\text { in disaster) }\end{array}$ & $\mathbf{0}$ & 0.4 & 0.4 & 0.4 & 0.3 & 0.4 & 0.4 \\
\hline \multicolumn{8}{|c|}{ Variables } \\
\hline Expected equity rate & 0.128 & 0.071 & 0.076 & 0.044 & 0.071 & 0.051 & 0.061 \\
\hline Expected & 0.127 & 5 & $0.061-$ & -0.007 & 0.029 & 0.015 & 0.025 \\
\hline Equity premium & 0.0016 & 0.036 & 0.016 & 0.052 & 0.042 & 0.036 & 0.036 \\
\hline $\begin{array}{l}\text { Expected equity rate, } \\
\text { conditional }\end{array}$ & 0.128 & 0.076 & 0.081 & 0.052 & 0.076 & 0.056 & 0.066 \\
\hline Face bill rate & 0.127 & 0.037 & $0.063-$ & -0.004 & 0.031 & 0.017 & 0.027 \\
\hline $\begin{array}{l}\text { Equity premium, } \\
\text { conditional }\end{array}$ & 0.0016 & 0.039 & 0.019 & 0.056 & 0.045 & 0.039 & 0.039 \\
\hline Price-earnings ratio & 9.7 & & 17.8 & 37.0 & 19.6 & 27.8 & 24.4 \\
\hline Expected growth rate & 0.025 & 0.020 & 0.020 & 0.018 & 0.020 & 0.015 & 0.020 \\
\hline $\begin{array}{l}\text { Expected growth rate, } \\
\text { conditional }\end{array}$ & 0.025 & 0.025 & 0.025 & 0.025 & 0.025 & 0.020 & 0.025 \\
\hline \multicolumn{8}{|c|}{ Levered results (debt-equity ratio is $\lambda=0.5$ ) } \\
\hline Expe & 0.129 & & 0.084 & 0.071 & 0.092 & 0.069 & 0.079 \\
\hline Equity premium & 0.0024 & 0.054 & 0.024 & 0.078 & 0.063 & 0.059 & 0.054 \\
\hline $\begin{array}{l}\text { Expected equity rate, } \\
\text { conditional }\end{array}$ & 0.129 & 0.096 & 0.091 & 0.080 & 0.099 & 0.076 & 0.086 \\
\hline $\begin{array}{l}\text { Equity premium, } \\
\text { conditional }\end{array}$ & 0.0024 & 0.059 & 0.028 & 0.084 & 0.068 & 0.059 & 0.059 \\
\hline
\end{tabular}

Cells show the calibrated model's rates of return and growth rates, based on the indicated parameter values. The distribution of disaster sizes $b$ comes from Table I (Figure I, panel A). The expected rate of return on equity is in (9). The expected rate of return on bills is in (12). The equity premium is the difference between these two rates. The expected rate of return on equity conditioned on no disasters is in (10). The face bill rate is in (11). The equity premium conditioned on no disasters is the difference between these two rates. The price-earnings ratio is in (17). The expected growth rate is in (18), and the expected growth rate conditioned on no disasters is in (19). The levered expected rate of return on equity is in (22), and the levered equity premium is in (23). Conditioning on no disasters raises the levered expected return on equity by $p \cdot E b \cdot(1+$ $\lambda-q \lambda)$ and the levered equity premium by $(1+\lambda) \cdot p \cdot(1-q) \cdot E b$. 
miums and bill rates. One consequence of raising $p$ from 0 (column (1)) to 0.017 is that the expected real bill rate falls dramatically-from 0.127 to 0.035 . The inverse relation between $p$ and $\log \left[E_{t}\left(R_{t 1}^{b}\right)\right]$ applies generally in (12); when $\theta=4$, the coefficient on $p$ is -5.3 .

Less intuitively, a rise in $p$ also lowers the expected rate of return on equity, $\log \left[E_{t}\left(R_{t 1}^{e}\right)\right]$, given in (9). If $\theta>1$, this change partly reflects an increase in the P-E ratio in (17) - when $p=$ 0.017 , the ratio of 19.6 in Table $\mathrm{V}$, column (2), exceeds the value 9.7 for $p=0$ in column (1). ${ }^{25}$ Intuitively, a rise in $p$ motivates a shift toward the risk-free asset and away from the risky one- this force would lower the P-E ratio. However, households also want to hold more assets overall because of greater uncertainty about the future. If $\theta>1$, this second force dominates, leading to a net increase in the P-E ratio. Even if $\theta<1$, the negative effect of $p$ on $\log \left[E_{t}\left(R_{t 1}^{e}\right)\right]$ applies in (9). The reason is that a rise in $p$ lowers the expected growth rate of dividends, $E_{t}\left(A_{t+1} / A_{t}\right)$, and this force makes the overall effect negative if $\theta>0$. In any event, the expected rate of return on equity falls by less than the expected bill rate, so that the equity premium increases in (13).

With no leverage, the equity premium in Table V, column (2), is $0.036 .{ }^{26}$ With a debt-equity ratio of $\lambda=0.5$, the premium is multiplied by 1.5 to get 0.054 . Hence, if $\theta=4$, the levered equity premium in the calibrated model is in the neighborhood of the empirical observations in Table IV.

As mentioned before, consideration of labor income and of a variable ratio of consumption to GDP might raise the effective leverage coefficient, $\lambda$. With $\lambda=1$, the levered equity premium in the baseline specification is 0.072 , close to observed values.

The results are sensitive to the coefficient of relative risk aversion, $\theta$. Table $\mathrm{V}$, column (3), assumes that $\theta=3$. In this case, the levered equity premium is only 0.024 , and the expected bill rate is unrealistically high -0.061 .

The results also depend on the disaster probability $p$. Since

25. If $\theta>1$, an increase in $p$ raises the $\mathrm{P}-\mathrm{E}$ ratio if $v_{t}$ is a global shock, such as a world war or global depression. This result also applies to a shock for a single country if the country is isolated from the rest of the world. However, if a country is integrated into world asset markets, an increase in the country-specific probability $p_{i}$ of a disaster lowers the P-E ratio for equity claims on country $i$ 's product (for any $\theta$ ).

26. If I include the 21 additional contractions in the interval between 0.10 and 0.14 (see note 9 ), the expected equity rate falls to 0.068 , the expected bill rate falls to 0.032 , and the equity premium is still 0.036 (higher by 0.0003 than in the setting without the 21 events). 
the term $\theta \sigma^{2}$ is small, the equity premium is nearly proportional to $p$ in (13); when $\theta=4$, the coefficient on $p$ is 2.0 . With a leverage ratio of $\lambda=0.5$, this coefficient is multiplied by 1.5 to get 3.0. Thus, comparing columns (2) and (4) of Table $\mathrm{V}$, an increase in $p$ from 0.017 to 0.025 raises the levered equity premium from 0.054 to 0.078 .

For a given disaster probability $p$ and distribution of disaster sizes $b$, a decrease in the contingent probability of default, $q$, raises the equity premium. ${ }^{27}$ That is, a lower $q$ means that bills tend to do better relative to stocks during disasters-hence, the equity premium increases. A comparison of columns (2) and (5) of Table $\mathrm{V}$ shows that a decrease in $q$ from 0.4 to 0.3 raises the levered equity premium from 0.054 to 0.063 .

Columns (6) and (7) of Table V consider changes in the growth rate, $\gamma$, and the rate of time preference, $\rho$. These parameters do not affect the equity premium but do affect levels of rates of return and the price-earnings ratio.

The results depend a lot on how bad disasters are, as gauged by the distribution of $b$. The results in Table $\mathrm{V}$ use the empirical distribution for disaster sizes in Figure I, panel A, for which the mean of $b$ is 0.29 . However, the various asset returns are nonlinear in $b$, for example, the equity premium in (13) depends on the terms $E(1-b)^{-\theta}$ and $E(1-b)^{1-\theta}$. This dependence means that, for given $\theta$, the effective weighted average of the $b$ 's for determining the equity premium gives more weight to the larger contractions. Moreover, for a given distribution of disaster sizes, the effective weighted average of the $b$ 's is larger the higher is $\theta$.

Figure II brings out the role of the $b$ variable by comparing three scenarios. The middle curve corresponds to the historical frequency of disaster sizes (Figure I, panel A) and, therefore, to Table V. The lower curve applies when $b$ is constant at the high value 0.5 , and the upper curve when $b$ is constant at the low value 0.25 . Each curve shows the combinations of the coefficient of relative risk aversion $(\theta)$ and probability of disaster $(p)$ needed to generate a levered equity premium equal to the historical value of $0.07 .^{28}$ Each curve assumes that the other parameters are set at

27. A lower default size, $d$, would have the same effect-the product $q d$ matters for pricing.

28. The transversality condition given in note 18 does not hold for high enough $\theta$. Violations occur for the historical distribution of $b$ when $\theta>5$.16, for $b=0.5$ when $\theta>3.73$, and for $b=0.25$ when $\theta>10.55$. However, it is always possible to satisfy the transversality condition by choosing a high enough $\rho$. Since 


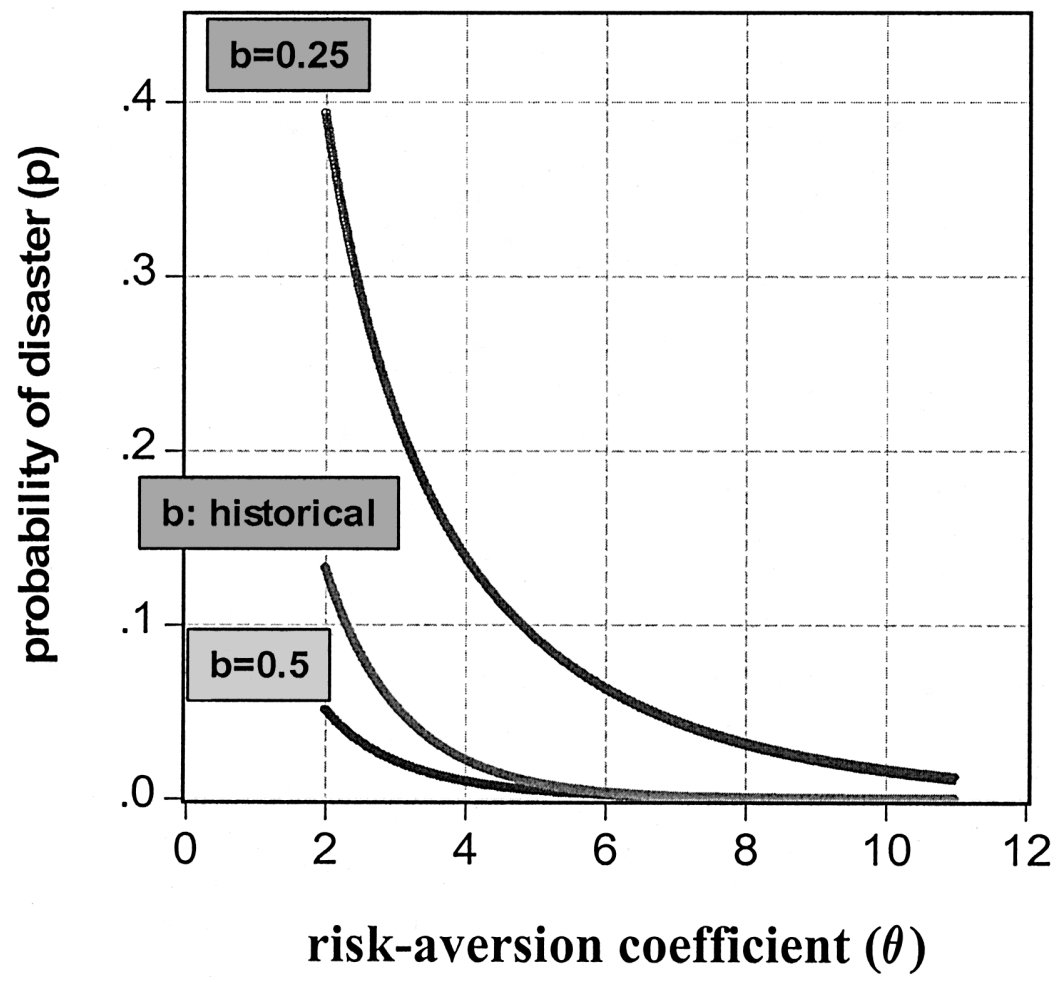

FiguRE II

Isopremium Curves

The graphs show the combinations of the disaster probability $(p)$ and the coefficient of relative risk aversion $(\theta)$ needed to generate a levered equity premium of 0.07 in (23) with a leverage coefficient, $\lambda$, of 0.5 . The middle graph uses the historical frequency of disaster sizes $b$, given in Figure I, panel A. In the lowest graph, $b$ is constant at 0.5 , and in the upper graph, $b$ is constant at 0.25 .

the baseline values from Table $\mathrm{V}$, column (2)—in particular, the debt-equity ratio is $\lambda=0.5$, the contingent probability of default is $q=0.4$, and the size of default is $d=b$.

When $\theta=2$, the position of the middle curve in Figure II signifies that the effective weighted average of the observed frequency distribution of the $b$ 's (which have a mean of 0.29 ) is between 0.25 and 0.50 but closer to the lower curve, which cor-

$\rho$ does not affect the equity premium, the curves shown in Figure II still apply with this adjustment to $\rho$. 
responds to $b=0.5$. As $\theta$ rises, the effective weighted average of the observed $b$ 's increases-therefore, the middle curve gets even closer to the lower curve.

One way to use Figure II is to calculate the value of $\theta$ needed to generate a levered equity premium of 0.07 when the disaster probability is set at its baseline value of $p=0.017$. The answer is $\theta=4.3$ for the historical distribution (middle curve), $\theta=3.3$ when $b=0.5$, and $\theta=10.0$ when $b=0.25$.

Another way to use Figure II is to compute the values of $p$ required to generate a levered equity premium of 0.07 when $\theta$ is fixed, say at 4 . For the historical distribution of $b$, the required value of $p$ is 0.022 . In contrast, when $b=0.5$, the required value of $p$ is 0.010 , and when $b=0.25$, the required value is 0.139 .

Campbell [2000] observes that Rietz's low-probability disasters create a "peso problem" when disasters are not observed within sample. Indeed, data availability tends to select no-disaster samples, as observed by Jorion and Goetzmann [1999]. However, this consideration turns out not to be quantitatively so important in the model.

Conditioning on no-disaster samples raises the expected rate of return on equity by $p \cdot E b$, as shown by a comparison of (9) with (10). With leverage, conditioning on no disasters eliminates the terms involving $E b$ in (22). Therefore, the expected rate of return on levered equity rises by $p \cdot E b \cdot(1+\lambda-q \lambda)$. With the parameters used in columns (2) and (3) of Table V ( $p=0.017$, $E b=0.29$, and $\lambda=0.5$ ), this expression equals 0.0063 . Therefore, the levered expected returns on equity conditioned on no disasters are higher by this amount than the full-sample returns.

Because of the default possibility on bills, conditioning on no disasters raises the expected rate of return on bills by $p q$. $E b$-see (11) and (12). With the parameters in columns (2) and (3) of Table V, this term equals 0.002 . Therefore, the face bill returns exceed the expected bill rates by this amount.

On net, conditioning on no disasters raises the levered equity premium by the expression $(1+\lambda) \cdot p \cdot(1-q) \cdot E b$. This term equals 0.004 with the parameters $(\lambda=0.5, p=0.017, q=0.4$, and $E b=0.29$ ) in columns (2) and (3) of Table V. Therefore, the equity premiums conditioned on no disasters are higher by this amount than the full-sample premiums.

Finally, conditioning on no disasters raises the expected growth rate by the term $p \cdot E b$ in (18). With the parameters in columns (2) and (3) of Table V, this term is 0.005 . Therefore, the 
growth rates conditioned on no disasters are higher by this amount.

The point is that the selection of no-disaster samples-a selection often driven by data availability — has only moderate effects on average rates of return on equity and bills, the equity premium, and economic growth rates. Nevertheless, the potential for these disasters has major effects on rates of return and the equity premium.

\section{DURation of Disasters}

In the model, disasters last for an instant of time, but in the data economic crises persist for varying numbers of years (Table I). In using the data to assess the distribution of disaster sizes, $b$, I used the cumulative falls in real per capita GDP during the crises (Figure I, panel A). A better procedure would allow for two regimes-normal and crisis-with transition probabilities between the two. The probability $p$ governs shifts from normal to crisis periods. Another probability could govern transitions from crisis to normal (and thereby determine the frequency distribution for lengths of wars and financial crises). During a crisis, output might fall steadily or, at least, the probability of substantial decline is much greater than at normal times.

This extension requires a deviation from one of the core simplifying assumptions of the analysis, i.i.d. shocks. This assumption, along with the existence of a representative agent, generates simple, closed-form results that explain a lot about asset returns. Moreover, this setup admits a number of rich complications, including a distribution of disaster sizes, default probability on bills, and leverage. Because of these benefits, I am reluctant to abandon the i.i.d. assumption, at least in the present analysis. However, a discrete-period version of the i.i.d. model may give some idea of the likely consequences from allowing for a full treatment of disaster regimes.

My initial setup used discrete periods but then allowed the arbitrary period length to approach zero. Now I reintroduce discrete periods and denote the length by $T$. The parameter $T$ represents, among other things, the fixed length of disasters. Thus, differences in $T$ indicate how the results depend on the average duration of disasters.

Application of the pricing formula from (4) leads to equations 
for the expected rates of return on equity and bills over discrete periods of length $T$ :

$$
\begin{aligned}
\left(\frac{1}{T}\right) \cdot \log \left[E_{t}\left(R_{t T}^{r}\right)\right] & =\rho+\theta \gamma-(1 / 2) \theta^{2} \sigma^{2}+\theta \sigma^{2} \\
& +\left(\frac{1}{T}\right) \cdot \log \left\{\frac{e^{-p T}+\left(1-e^{-p T}\right) \cdot(1-E b)}{e^{-p T}+\left(1-e^{-p T}\right) \cdot E(1-b)^{1-\theta}}\right\}
\end{aligned}
$$

$$
\begin{aligned}
\left(\frac{1}{T}\right) \cdot \log \left[E_{t}\left(R_{t T}^{b}\right)\right]=\rho+\theta \gamma \\
-\left(\frac{1}{2}\right) \theta^{2} \sigma^{2}+\theta \sigma^{2}-\left(\frac{1}{T}\right) \cdot \log \left\{e^{-p T}+\left(1-e^{-p T}\right)\right. \\
\left.\cdot\left[(1-q) \cdot E(1-b)^{-\theta}+q \cdot E(1-b)^{1-\theta}+q \cdot E b\right]\right\} .
\end{aligned}
$$

These formulas reduce to (9) and (12), respectively, as $T$ approaches zero.

The allowance for persisting crises suggests reconsideration of the measured disaster sizes, $b$. Since crises last for a finite interval, the raw numbers (Figure I, panel A) do not accurately measure the proportionate effect on output due to the crisis. The observed declines in real per capita GDP over intervals of varying lengths (Table I) should be adjusted to allow for normal growth over the crisis periods. This adjustment-using the parameter values $\gamma=0.025$ and $\sigma=0.02$ and the number of years applicable to each crisis-results in the distribution of disaster sizes shown in Figure I, panel B. This adjustment is substantial-the mean of $b$ rises from 0.29 to 0.35 .

Table VI shows the model's expected rates of return on equity and bills and the equity premium for different settings of the period length, $T$. The upper part of the table assumes that $\theta=4$, and the lower part uses $\theta=3$. The other parameters are the baseline values from Table V, column (2). The first row of each panel in Table VI assumes that $T=0$ and makes no trend adjustment to the $b$ values. These results correspond to Table V, columns (2) and (3). The second row of each panel in Table VI maintains $T=0$ but adjusts the disaster sizes for trend (using a different number of years for each crisis in Table I). This upward adjustment to $b$ substantially affects the expected rates of return and the equity premium. When $\theta=4$, the unlevered equity premium is now 0.064 , rather than 0.036 , and the expected bill rate is -0.020 , rather than 0.035 . 
TABLE VI

Effect of Period Length on Equity and Bill Rates

\begin{tabular}{lcccc}
\hline \hline (1) & $\begin{array}{c}(2) \\
\text { Period length } \\
T \text { (years) }\end{array}$ & $\begin{array}{c}(3) \\
\text { Expected equity } \\
\text { rate (unlevered) }\end{array}$ & $\begin{array}{c}(4) \\
\text { Expected } \\
\text { bill rate }\end{array}$ & $\begin{array}{c}\text { Equity premium } \\
\text { (unlevered) }\end{array}$ \\
\hline detrended? & & $\theta=4$ & & \\
No & 0 & 0.071 & 0.035 & 0.036 \\
Yes & 0 & 0.044 & -0.020 & 0.064 \\
Yes & 3 & 0.054 & 0.008 & 0.046 \\
Yes & 5 & 0.059 & 0.020 & 0.038 \\
No & 0 & $0=3$ & & \\
Yes & 0 & 0.076 & 0.061 & 0.016 \\
Yes & 3 & 0.066 & 0.041 & 0.025 \\
Yes & 5 & 0.068 & 0.047 & 0.021 \\
\hline \hline
\end{tabular}

The cells show the expected equity and bill rates and the equity premium in the discrete-period model with period length $T$. Column (1) indicates whether the distribution of disaster sizes $b$ is computed from raw data (Figure I, panel A) or trend-adjusted values (Figure I, panel B). The expected equity rate in column (3) comes from (25). The expected bill rate in column (4) comes from (26). The equity premium in column (5) is the difference between these two rates.

The allowance for a higher $T$ in (25) and (26) essentially reverses the effects from the trend adjustments to the $b$ values. The reason is that, at the beginning of any period, the uncertain future is more distant when $T$ is larger. Table VI shows that, for $T$ between three and five years, the equity premium is somewhat higher and the expected bill rate somewhat lower than the values in the original model (Table V, columns (2) and (3)).

In the $T$-period model, the rates of return refer to periods of length $T$. Therefore, in matching the data with the model, it would be reasonable to calculate equity premiums by comparing equity returns with returns on longer term bonds, rather than short-term bills. In practice, this change does not substantially alter the empirical picture. For 1880 to 2004, using data from Global Financial Data, the average real rate of return on ten-year maturity U. S. government bonds was 2.3 percent, compared with 1.5 percent for bills. From 1919 to 2004, the average real rate of return on five-year maturity U. S. government bonds was 2.4 percent, compared with 2.7 percent on ten-year bonds and 1.0 percent on bills. Thus, instead of 7 percent, the U. S. equity premium calculated from longer term bonds is around 6 percent.

My inference from Table VI is that the main results would not change greatly by extending the model to allow for crises of 
finite and varying lengths. However, a worthwhile extension would deal more seriously with the dynamics of crisis regimes.

\section{Rare Disasters and the Bill Rate}

The results in Table $\mathrm{V}$ apply when $p$ and $q$ and the other parameters are fixed; for example, $p=0.017$ per year, and $q=$ 0.4 . The results also show the effects from permanent, unanticipated changes in any of the parameters, such as $p$ and $q$. I now use the model to assess the effects from changes in $p$ and $q$. However, in a full analysis, stochastic variations in $p$ and $q$ would be part of the model.

An increase in $p$ reduces the expected bill rate in (12) and the face bill rate in (11). With the parameters in Table V, column (2), including $\theta=4$, the coefficient on $p$ in (12) is -5.3 . Therefore, if $p$ rises permanently from 0.017 to 0.025 , the expected bill rate falls from 0.035 (column (2)) to -0.007 (column (4)). Mehra and Prescott [1988, p. 135] criticized the analogous prediction from Rietz's [1988] analysis:

Perhaps the implication of the Rietz theory that the real interest rate and the probability of the extreme event move inversely would be useful in rationalizing movements in the real interest rate during the last 100 years. For example, the perceived probability of a recurrence of a depression was probably high just after World War II and then declined. If real interest rates rose significantly as the war years receded, that would support the Rietz hypothesis. But they did not. . . Similarly, if the low-probability event precipitating the large decline in consumption were a nuclear war, the perceived probability of such an event surely has varied in the last 100 years. It must have been low before 1945, the first and only year the atom bomb was used. And it must have been higher before the Cuban Missile Crisis than after it. If real interest rates moved as predicted, that would support Rietz's disaster scenario. But again, they did not.

The general point about the probability of depression makes sense, but I am skeptical that the end of World War II raised this probability. I consider later the likely movements in disaster probability associated with the Great Depression itself.

The observations about the probability of nuclear war confuse, in my terminology, the disaster probability, $p$, and the conditional expected probability of default, $q$. A heightened chance of nuclear war likely raises $p$ but also substantially increases $q$-because defaults on bills would be highly probable in the wake of a nuclear conflict, especially if it led to the end of the 
world! $!^{29}$ Although an increase in $p$ lowers the expected bill rate in (12), a rise in $q$ has the opposite effect. Thus, for an event such as the Cuban missile crisis, the predicted effect on the expected bill rate is ambiguous.

Changing probabilities of depression would likely isolate the effect of changing $p$, because defaults on bills are atypical in these situations. However, we have to identify the variations in depression probability that occurred over time or across countries. From a U.S. perspective, the onset of the Great Depression in the early 1930s likely raised $p$ (for the future). The recovery from 1934 to 1937 probably reduced $p$, but the recurrence of sharp economic contraction in 1937-1938 likely increased $p$ again. Less clear is how the end of World War II affected $p$.

The events shown in Table I suggest consideration of changing probability of the types of wars seen in history-notably World Wars I and II, which were massive but not the end of the world in the manner that might be implied by a nuclear conflict. My assumption is that the occurrence of this type of war raised $p$ and $q$, that is, increased the perceived probabilities of future disasters and of future defaults on bills. Starting from the baseline values $p=0.017$ and $q=0.4$, using the historical distribution of the $b$ 's in Figure I, panel A, and assuming that $\theta=4$, increases in $p$ and $q$ imply a net reduction in the expected bill rate if the following inequality holds:

$$
\Delta p / p>0.25 \cdot \Delta(q / q) .
$$

For example, if a war raises $p$ by 0.001 (from 0.017 to 0.018 ), this inequality would be violated only if $q$ rises by at least 0.09 (from 0.40 to 0.49 ). I assume that this inequality holds during the U. S. wars. In that case, the model predicts that the occurrence of war reduces the expected bill rate in (12) and the face bill rate in (11).

Figure III shows an estimated time series since 1859 of the expected real interest rate on U. S. Treasury Bills or analogous

29. The chance of loss of property rights on equity claims-assumed to be zero in my analysis - would also be significant here. I considered using the famous "doomsday clock," discussed by Slemrod [1986], to assess empirically the changing probability of nuclear war. The clock is available online from the Bulletin of the Atomic Scientists. I decided not to use these "data" because the settings reflect an ideology that always identifies toughness with higher probability of nuclear war and disarmament with lower probability. For example, the clock was nearly at its worst point - three minutes to midnight-in 1984 shortly after President Reagan began his successful confrontation of the "evil empire" of the Soviet Union. 


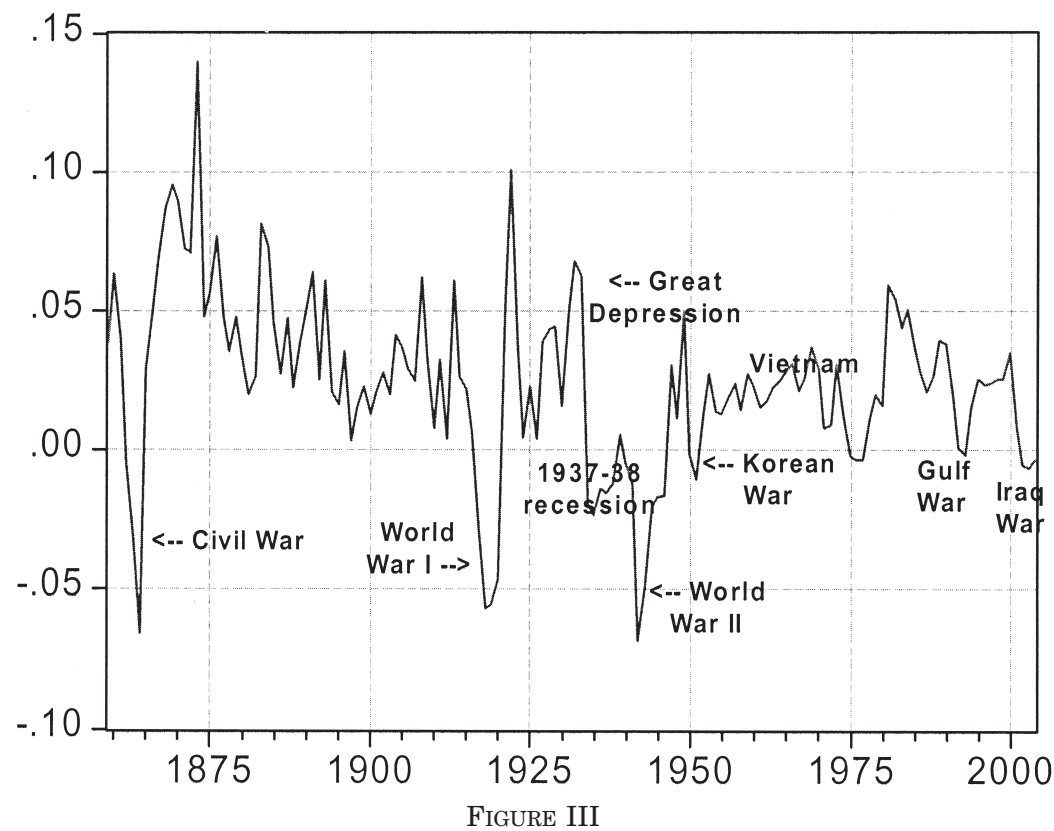

Expected Real Interest Rate on U. S. T-Bills/Commercial Paper, 1859-2004

Data on nominal returns on U. S. Treasury Bills (1922-2004) and Commercial Paper (1859-1921) are from Global Financial Data. See the notes to Table IV. From 1947-2004, expected real returns are nominal returns less the Livingston expected inflation rate for the CPI (using six-month-ahead forecasts from June and December). For 1859-1946 the expected real return is the nominal return less a constructed estimate of expected inflation derived from a first-order autoregression of CPI inflation rates for 1859-1946. The CPI data are from Bureau of Labor Statistics (January values since 1913, annual averages before 1913) and U. S. Department of Commerce [1975].

short-term paper. ${ }^{30}$ To compute the expected real interest rate, I subtracted an estimate of the expected inflation rate for the CPI. Since 1947, my measure of expected inflation is based on the Livingston Survey. From 1859 to 1946, I measured the "expected inflation rate" as the fitted value from an autoregression of annual CPI inflation on a single lag. ${ }^{31}$ Additional lags lack explana-

30. The source of data on nominal returns is Global Financial Data, the same as in Table IV. Before the introduction of T-Bills in 1922, the data refer to high-grade commercial paper. It would be preferable to look at returns on indexed bonds, but these instruments exist in the United States only since 1997.

31. The inflation rate is the January-to-January value from 1913 to 1946. Before 1913, the CPI data are something like annual averages. The estimated lag coefficient is 0.62 (s.e. $=0.09$ ). The $R^{2}$ for this regression is 0.35 . 
tory power, although there may be a long-run tendency over this period for the price level to adjust toward a stationary target.

One striking observation from Figure III is that the expected real interest rate tended to be low during wars-especially the Civil War, World War I, and World War II. The main exception is the Vietnam War. ${ }^{32}$ Table VII shows the nominal interest rate, expected inflation rate, and expected real interest rate during each war and the Great Depression. The typical wartime pattern-applicable to the Civil War, World Wars I and II, and the first part of the Korean War-is that the nominal interest rate changed little, while actual and expected inflation rates rose. Therefore, expected real interest rates declined, often becoming negative. Moreover, the price controls imposed during World War II and the Korean War likely led to an understatement of inflation; therefore, the expected real interest rate probably declined even more than shown for these cases.

Figure III and Table VII show that expected real interest rates fell in 2001-2003 during the most recent war-a combination of the September 11 attacks and the conflicts in Afghanistan and Iraq. This period also has data on real yields on U. S. Treasury indexed bonds, first issued in 1997. The ten-year real rate fell from an average of 3.8 percent for $1 / 97-8 / 01$ to 2.2 percent for $10 / 01-8 / 05 .{ }^{33}$ Similarly, the five-year real rate declined from an average of 3.2 percent for $12 / 00-8 / 01$ to 1.6 percent for 10/01-8/05. These real rate reductions on indexed bonds accord with those shown for the short-term "expected real rate" in Table VII. ${ }^{34}$

The tendency for expected real interest rates to be low during U. S. wars has been a mystery, described in Barro [1997, Ch.

32. Taxation of nominal interest income along with an increase in the expected inflation rate may explain the Vietnam pattern. That is, expected after-tax real interest rates were low.

33. The indexed bonds data show that risk-free real interest rates are not close to constant. For ten-year U. S. indexed bonds, the mean for 1/97-8/05 was 3.0 percent, with a standard deviation of 0.9 percent and a range from 1.5 percent to 4.3 percent. For the United Kingdom from $2 / 83-8 / 05$, the mean real rate on ten-year indexed bonds was 3.2 percent, with a standard deviation of 0.8 percent and a range from 1.5 percent to 4.6 percent.

34. The real rate on ten-year indexed bonds peaked at 4.2 percent in May 2000 then fell to 3.3 percent in August 2001-perhaps because of the end of the Internet boom in the stock market but obviously not because of September 11 or the Afghanistan-Iraq wars. However, the rate then fell to 3.0 percent in October 2001 and, subsequently, to 1.8 percent in February 2003. The lowest level was 1.5 percent in March 2004. 
TABLE VII

Interest ANd INFLATion RAtes DURING WaRS AND the GREat Depression IN THE UNITED STATES

\begin{tabular}{|c|c|c|c|}
\hline Year & $\begin{array}{l}\text { Nominal } \\
\text { return }\end{array}$ & $\begin{array}{c}\text { Expected } \\
\text { inflation rate }\end{array}$ & $\begin{array}{l}\text { Expected real } \\
\text { return }\end{array}$ \\
\hline \multicolumn{4}{|l|}{ Civil War } \\
\hline 1860 & 0.070 & 0.006 & 0.063 \\
\hline 1861 (start of war) & 0.066 & 0.026 & 0.039 \\
\hline 1862 & 0.058 & 0.063 & -0.005 \\
\hline 1863 & 0.051 & 0.082 & -0.031 \\
\hline 1864 & 0.062 & 0.128 & -0.066 \\
\hline 1865 (end of war) & 0.079 & 0.050 & 0.029 \\
\hline \multicolumn{4}{|l|}{ Spanish-American War } \\
\hline 1897 & 0.018 & 0.015 & 0.004 \\
\hline 1898 (year of war) & 0.021 & 0.006 & 0.015 \\
\hline \multicolumn{4}{|l|}{ World War I } \\
\hline 1914 (start of war) & 0.047 & 0.021 & 0.026 \\
\hline 1915 & 0.033 & 0.011 & 0.022 \\
\hline 1916 & 0.033 & 0.026 & 0.007 \\
\hline 1917 (U. S. entrance) & 0.048 & 0.075 & -0.028 \\
\hline 1918 (end of war) & 0.059 & 0.116 & -0.057 \\
\hline \multicolumn{4}{|l|}{ Great Depression } \\
\hline 1929 & 0.045 & 0.000 & 0.044 \\
\hline 1930 (start of depression) & 0.023 & 0.006 & 0.016 \\
\hline 1931 & 0.012 & -0.038 & 0.050 \\
\hline 1932 & 0.009 & -0.059 & 0.068 \\
\hline 1933 (worst of depression) & 0.005 & -0.057 & 0.062 \\
\hline 1934 & 0.003 & 0.022 & -0.020 \\
\hline 1935 & 0.002 & 0.025 & -0.023 \\
\hline 1936 & 0.002 & 0.015 & -0.014 \\
\hline 1937 (onset of sharp recession) & 0.003 & 0.018 & -0.016 \\
\hline 1938 & 0.001 & 0.012 & -0.012 \\
\hline \multicolumn{4}{|l|}{ World War II } \\
\hline 1939 (start of war) & 0.000 & -0.005 & 0.006 \\
\hline 1940 & 0.000 & 0.005 & -0.005 \\
\hline 1941 (U. S. entrance) & 0.001 & 0.014 & -0.012 \\
\hline 1942 & 0.003 & 0.072 & -0.068 \\
\hline 1943 & 0.004 & 0.053 & -0.049 \\
\hline 1944 & 0.004 & 0.024 & -0.021 \\
\hline 1945 (end of war) & 0.004 & 0.021 & -0.017 \\
\hline \multicolumn{4}{|l|}{ Korean War } \\
\hline 1950 (start of war) & 0.012 & 0.014 & -0.002 \\
\hline 1951 & 0.016 & 0.026 & -0.010 \\
\hline 1952 & 0.017 & 0.005 & 0.012 \\
\hline 1953 (end of war) & 0.019 & -0.009 & 0.028 \\
\hline \multicolumn{4}{|l|}{ Vietnam War } \\
\hline 1964 & 0.036 & 0.011 & 0.025 \\
\hline 1965 (start of main war) & 0.041 & 0.012 & 0.029 \\
\hline
\end{tabular}


TABLE VII

(CONTINUED)

\begin{tabular}{lccc}
\hline \hline \multicolumn{1}{c}{ Year } & $\begin{array}{c}\text { Nominal } \\
\text { return }\end{array}$ & $\begin{array}{c}\text { Expected } \\
\text { inflation rate }\end{array}$ & $\begin{array}{c}\text { Expected real } \\
\text { return }\end{array}$ \\
\hline 1966 & 0.049 & 0.018 & 0.031 \\
1967 & 0.044 & 0.022 & 0.022 \\
1968 & 0.055 & 0.029 & 0.026 \\
1969 & 0.069 & 0.032 & 0.037 \\
1970 & 0.065 & 0.036 & 0.029 \\
1971 (end of main war) & 0.044 & 0.035 & 0.008 \\
1972 (enar & 0.042 & 0.033 & 0.009 \\
Gulf War & & & \\
1991 (year of war) & 0.077 & 0.039 & 0.038 \\
1992 & 0.054 & 0.035 & 0.020 \\
Afghanistan-Iraq War & 0.035 & 0.034 & 0.001 \\
2000 & & & \\
2001 (September 11) & 0.058 & 0.025 & 0.033 \\
2002 (start of Afghanistan war) & 0.033 & 0.025 & 0.008 \\
2003 (start of Iraq war) & 0.016 & 0.022 & -0.006 \\
2004 & 0.010 & 0.017 & -0.006 \\
\hline \hline
\end{tabular}

Nominal returns on U. S. Treasury Bills or commercial paper (before 1922) are calculated as in Table IV. The expected inflation rate for the CPI is constructed as described in the notes to Figure III. The expected real return is the difference between the nominal return and the expected inflation rate.

12]. ${ }^{35}$ Most macroeconomic models predict that a massive, temporary expansion of government purchases would raise expected real interest rates. In previous work, I conjectured that military conscription and mandated production might explain part of the puzzle. Mulligan [1997] attempted to explain the World War II data by invoking a large increase of labor supply due to patriotism. A complementary idea is that patriotism and rationing motivated increases in saving, perhaps concentrated on war bonds. However, the low real interest rate in wartime seems too pervasive to be explained by these special factors. The rare-disasters framework offers a more promising explanation: expected real interest rates tend to fall in wartime because of increases in the perceived probability, $p$, of future economic disaster.

Table VII also shows U. S. expected real interest rates during

35. Barro [1987] finds that interest rates were high during U. K. wars from 1701 to 1918 . However, this evidence pertains to nominal, long-term rates. Shortterm interest rates are unavailable for the long U. K. history, but realized short-term real rates were low during World Wars I and II. 
the Great Depression. According to the theory, this rate should have declined if the probability $p$ of disaster increased. Matching this prediction to the data is difficult because of uncertainty about how to gauge expected inflation during a time of substantial deflation.

The nominal return on Treasury Bills fell from over 4 percent in 1929 to 2 percent in 1930, 1 percent in 1931, and less than 1 percent from 1932 on. However, the inflation rate became substantially negative ( -2 percent in $1930,-9$ percent in $1931,-11$ percent in $1932,-5$ percent in 1933), and the constructed expected inflation rate also became negative: -4 percent in 1931 and -6 percent in 1932 and 1933. Therefore, the measured expected real interest rate was high for 1931-1933. However, this construction is likely to be erroneous because the deflation in 1931-1933 depended on a series of monetary/financial shocks, each of which was unpredictable from year to year. Hence, rational agents likely did not anticipate much of this deflation. This perspective accords with Hamilton's [1992] observation that futures prices on several commodities remained well above spot prices during the early 1930 s. Hence, I think that expected real interest rates were much lower in the early 1930s than the values reported in the table. From 1934 on, the inflation rate became positive. The combination of positive expected inflation with nominal interest rates close to zero generated low expected real interest rates for 1934-1938. This period includes the sharp recession-and possible fears of a return to depression-in 1937-1938.

\section{Volatility of Stock Returns}

The variance of the growth rate of $A_{t}$ is given in (24). In the baseline model in Table $\mathrm{V}$, column (2), the price-earnings ratio is constant. Therefore, the standard deviation of stock returns equals the standard deviation of the growth rate of $A_{t}$. When $p=$ 0.017 , this standard deviation equals 0.046 or 0.053 when disaster sizes $b$ have the distribution given by Figure I, panel A or B, respectively. These values apply to samples with representative numbers of disasters, such as the long periods considered in the upper part of Table III. However, the average standard deviation of stock returns over these periods was 0.23 (Table IV), way above the value predicted by the model. Similarly, the tranquil period 1954-2004 displayed in the lower part of Table III should corre- 
spond to the model conditioned on no disasters. In this case, the model standard deviation of stock returns is 0.02 (the value for $\sigma$ in the baseline specification), whereas the average standard deviation in the data was again 0.23 (Table IV). These discrepancies correspond to the excess-volatility puzzle for stock returns.

A natural way to resolve this puzzle is to allow for variation in underlying parameters, notably the probability $p$ of $v$-type disaster. Table $\mathrm{V}$ shows that the price-earnings ratio is sensitive to $p$. Comparing columns (2) and (4), an increase in $p$ from 0.017 to 0.025 raises the P-E ratio from 19.6 to 37.0 . As already noted, this change refers to a permanent shift in disaster probability. However, an extension of the model to allow for stochastic, persisting variations in $p_{t}$ may account for the observed volatility of stock returns.

To get an idea of the magnitudes, the annual standard deviation of the residuals from an $\mathrm{AR}(1)$ process for the log of the U. S. $\mathrm{P}-\mathrm{E}$ ratio is around 0.2 for December values from 1880 to 2004. If $\theta=4$ and $b$ has the frequency distribution given in Figure I, panel A, the coefficient on $p$ in the denominator of the formula for the $\mathrm{P}-\mathrm{E}$ ratio in (17) equals -3.0 . This coefficient implies that the effect of a change in $p$ on the proportionate change in the P-E ratio is 59 in the neighborhood of the baseline values used in Table V, column (2). Therefore, to generate an annual standard deviation for the log of the P-E ratio of 0.2 , the annual standard deviation of $p$ has to be around 0.0034 .

An important question is whether this variability in $p$ generates unrealistically large fluctuations in the expected bill rate, given in (12). The coefficient on $p$ in (12) with the baseline parameters is -5.4 . Therefore, an annual standard deviation for $p$ of 0.0034 generates a standard deviation of the expected real bill rate of 0.018 . The annual standard deviation of the residuals from an AR(1) process for December values of realized real rates of return on U. S. Treasury Bills or short-term commercial paper from 1880 to 2004 is 0.018 , equal to the predicted value. Therefore, the model does not seem to generate excessive volatility in real interest rates.

Another way to look at the results is in terms of the Sharpe ratio for equity, discussed in Campbell [2000]. The Sharpe ratio is the risk premium on equity divided by the standard deviation of the excess return on equity. In the long samples shown in Table IV, the Sharpe ratio is around 0.3. In the model, using the baseline parameters (Table V, column (2)), the ratio for the unlevered 
case is $0.036 / 0.046=0.8$. Thus, the risk premium is "too high" relative to the volatility of returns. My conjecture is that the introduction of variations in $p_{t}$ would generate a closer match between observed and theoretical Sharpe ratios. That is, the standard deviation of the excess return on stocks would increase, but the risk premium may not change greatly. This outcome would be anticipated if variations in $p_{t}$ are mostly orthogonal to current real GDP and consumption.

\section{Capital Formation}

The model neglected investment, that is, changes in the quantity of capital in the form of trees. Therefore, growth and fluctuations resulted from variations in the productivity of capital, $A_{t}$, with the quantity of capital, $K$, assumed fixed. To assess the implications of capital formation, it is convenient to consider the opposite setting, that is, a fixed productivity of capital, $A$, with the quantity of capital, $K_{t}$, allowed to vary.

The production function takes the " $A K$ " form:

$$
Y_{t}=A K_{t},
$$

where $Y_{t}$ is output of fruit, $K_{t}$ is the number of trees, and $A>0$ is constant. ${ }^{36}$ Output can be consumed (as fruit) or invested (as seed). The process of creating new trees through planting seeds is assumed, unrealistically, to be rapid enough so that, as in the conventional one-sector production framework, the fruit price of trees (capital) is pegged at a price normalized to one. In other words, I ignore adjustment costs for investment. This setting corresponds to having "Tobin's $q$ " always equal to one-unlike in the previous model, where the market price of trees was variable.

Depreciation of trees occurs at rate $\delta_{t}>0$. This rate includes a normal depreciation rate, $\delta>0$, plus a stochastic term, $v_{t}$, that reflects the types of disasters considered before. With probability $p>0$ in each period, a disaster occurs that wipes out the fraction $b$ of the trees. As before, the idea is that $p$ is small but $b$ is large.

Since the price of trees is fixed at one, the one-period gross return on tree equity can be calculated immediately as

$$
R_{t 1}^{e}=1+A-\delta-v_{t+1} .
$$

36. Temporary fluctuations in $A$ can be added to the model without affecting the main results. However, a positive trend in $A$ tends now to generate rising growth rates of output and capital stock. 
The assumed distribution for $v_{t+1}$ implies that the expected gross return on equity is

$$
E_{t}\left(R_{t 1}^{e}\right)=1+A-\delta-p \cdot E b .
$$

The usual asset-pricing formulas still apply. For equitywhich has to be priced in equilibrium at one-the formula is

$$
\left(C_{t}\right)^{-\theta}=e^{-\rho} \cdot E_{t}\left[\left(C_{t+1}\right)^{-\theta} \cdot\left(1+A-\delta-v_{t+1}\right)\right] .
$$

For the risk-free bill return, the result is

$$
\left(C_{t}\right)^{-\theta}=e^{-\rho} \cdot R_{t 1}^{f} \cdot E_{t}\left[\left(C_{t+1}\right)^{-\theta}\right],
$$

where $R_{t 1}^{f}$ is the one-period gross risk-free return. (A probability of default on bills could be added.)

To determine the risk-free return in (32), we have to know how output $Y_{t}$ divides up each period between consumption $C_{t}$ and gross investment $I_{t}$. In the present model, a change in the single state variable $K_{t}$ will generate equiproportionate responses of the optimally chosen $C_{t}$ and $I_{t}$. That is, $I_{t}$ will be a constant proportion $v$ of $K_{t}$. Using this fact in the context of (31) allows for the determination of $\nu$. The result, as the length of the period approaches zero, is

$$
v=\delta+(1 / \theta) \cdot\left[A-\rho-\delta+p \cdot E(1-b)^{1-\theta}-p\right] .
$$

Since $0<b<1$, an increase in $p$ raises $\nu$-the saving rate-if $\theta>1$.

Using (32), the formula for $v$ determines the risk-free return:

$$
R_{t 1}^{f}=1+A-\delta-p \cdot E(1-b)^{-\theta}+p \cdot E(1-b)^{1-\theta} .
$$

Using the formula for the risk-free bill return from (30), the equity premium is

$$
\begin{aligned}
& \text { equity premium }=E_{t}\left(R_{t 1}^{e}\right)-R_{t 1}^{f} \\
& =p \cdot\left[E(1-b)^{-\theta}-E(1-b)^{1-\theta}-E b\right] .
\end{aligned}
$$

This formula is the same as (13) from the original model, except for the omission of terms involving background noise $\sigma$ and default probability on bills, $q$.

The model with investment determines the growth rate of the economy, that is, the growth rate of the number of trees, $K_{t+1}$ / $K_{t}-1$, which equals the growth rate of output, $Y_{t+1} / Y_{t}-1$. As the period length approaches zero, the growth rate approaches 


$$
\begin{aligned}
K_{t+1} / K_{t}-1 & =v-\delta-v_{t+1} \\
& =(1 / \theta) \cdot\left[A-\rho-\delta+p \cdot E(1-b)^{1-\theta}-p\right]-v_{t+1}
\end{aligned}
$$

The expected growth rate is

$$
\begin{aligned}
E_{t}\left(K_{t+1} / K_{t}-1\right)=(1 / \theta) & \cdot(A-\rho-\delta) \\
+ & p \cdot\left\{(1 / \theta) \cdot\left[E(1-b)^{1-\theta}-1\right]-E b\right\} .
\end{aligned}
$$

The net effect of $p$ on the expected growth rate is ambiguous- the positive effect of $p$ on $v$ (if $\theta>1$ ) is offset by the direct negative impact of $p$ on the expected growth rate.

\section{Concluding Observations}

The allowance for low-probability disasters, suggested by Rietz [1988], explains a lot of puzzles about asset returns. Moreover, this approach achieves these explanations while maintaining the tractable framework of a representative agent, timeadditive and isoelastic preferences, complete markets, and i.i.d. shocks to productivity growth. The framework can be extended from Lucas' fixed-number-of-trees model to a setting with capital formation.

A natural next step is to extend the model to incorporate stochastic, persisting variations in the disaster probability $p_{t}$. This extension means that shocks are no longer i.i.d.; therefore, the analysis will be technically more difficult. With time-varying disaster probability, the empirical analysis could be extended to measure $p_{t}$ and to relate these probabilities to asset returns and consumption. Options prices on the overall stock market might help in the measurement of $p_{t} \cdot{ }^{37}$ Other possibilities include insurance premiums, contract prices in betting markets, and prices of precious commodities, such as gold and diamonds.

Another extension expands the asset menu to include real estate, so that housing prices could be related to disaster probabilities. The model's structure could also be generalized to allow for variations in the growth-rate parameter $\gamma$. Some of this variation could involve business-cycle movements-then the model might have implications for cyclical variations in rates of return and the equity premium. In an international context, a distinc-

37. Xavier Gabaix made this suggestion. Santa-Clara and Yan [2005] use $\mathrm{S} \& \mathrm{P}$ options prices to gauge the probability of jumps, which relate to the rare events that I consider. 
tion between local and global disasters could be applied to events such as regional financial crises.

In an international setting, the model has implications for failures of interest-rate parity conditions. Kugler and Weder [2005] observe that interest rates on Swiss-franc-denominated assets have been lower in the long run than those on deposits denominated in other major currencies after taking account of observed variations in exchange rates. Their favored explanation, consistent with the rare-disasters framework, is a "reverse-peso" problem. That is, investors anticipated that the Swiss franc would appreciate relative to other currencies in response to a disaster event-notably a major war-which happened not to materialize within sample. The rare-disasters framework may also help to explain some of the well-known short-run deviations from interest-rate parity conditions among other OECD countries.

HARVARD UNIVERSITY

\section{REFERENCES}

Barro, Robert J., "Government Spending, Interest Rates, Prices, and Budget Deficits in the United Kingdom, 1701-1918," Journal of Monetary Economics, XX (1987), 221-247.

- Macroeconomics, 5th ed. (Cambridge, MA: MIT Press, 1997).

Barro, Robert J., and Xavier Sala-i-Martin, Economic Growth, 2nd ed. (Cambridge, MA: MIT Press, 2004).

Bresciani-Turroni, Costantino, The Economics of Inflation (London, UK: George Allen \& Unwin, 1937).

Campbell, John Y., "Asset Pricing at the Millennium," Journal of Finance, LV (2000), 1515-1567.

Epstein, Lawrence G., and Stanley E. Zin, "Substitution, Risk Aversion, and the Temporal Behavior of Consumption I: A Theoretical Framework," Econometrica, LVII (1989), 937-990.

Feinstein, Charles H., National Income, Expenditure and Output of the United Kingdom, 1855-1965 (Cambridge, UK: Cambridge University Press, 1972).

Hamilton, James D., "Was the Deflation during the Great Depression Anticipated? Evidence from the Commodity Futures Market," American Economic Review, LXXXII (1992), 157-178.

Hayashi, Fumio, and Edward C. Prescott, "The 1990s in Japan: A Lost Decade," Review of Economic Dynamics, V (2002), 206-235.

Hubbard, R. Glenn, Jonathan Skinner, and Stephen P. Zeldes, "Precautionary Saving and Social Insurance," Journal of Political Economy, CIII (1995), 360-399.

Jorion, Philippe, and William N. Goetzmann, "Global Stock Markets in the Twentieth Century," Journal of Finance, LIV (1999), 953-980.

Kehoe, Timothy J., and Edward C. Prescott, "Great Depressions of the 20th Century," Review of Economic Dynamics, V (2002), 1-18.

Kendrick, John W., Productivity Trends in the United States (Princeton, NJ: Princeton University Press, 1961).

Kocherlakota, Narayana R., "Disentangling the Coefficient of Relative Risk Aversion from the Elasticity of Intertemporal Substitution: An Irrelevance Result," Journal of Finance, XLV (1990), 175-190. 
Kugler, Peter, and Beatrice Weder, "Why Are Returns on Swiss Franc Assets so Low? Rare Events May Solve the Puzzle," Applied Economics Quarterly, LI (2005), 231-246.

Lucas, Robert E., "Asset Prices in an Exchange Economy," Econometrica, XLVI (1978), 1429-1445.

Maddison, Angus, The World Economy: Historical Statistics (Paris: OECD, 2003).

McCulloch, J. Huston, "The Ban on Indexed Bonds, 1933-77," American Economic Review, LXX (1980), 1018-1021.

Mehra, Rajnish, and Edward C. Prescott, "The Equity Premium: A Puzzle," Journal of Monetary Economics, XV (1985), 145-161.

Mehra, Rajnish, and Edward C. Prescott, "The Equity Risk Premium: A Solution?" Journal of Monetary Economics, XXII (1988), 133-136.

Mehra, Rajnish, and Edward C. Prescott, "The Equity Premium in Retrospect," in George M. Constantinides, Milton Harris, and Rene Stulz, eds., Handbook of the Economics of Finance (Amsterdam: North-Holland, 2003).

Mitchell, Brian R., European Historical Statistics, 1750-1975 (London, UK: Macmillan, 1980).

_- International Historical Statistics: Africa and Asia (New York: New York University Press, 1982).

—- International Historical Statistics: The Americas and Australasia (London, UK: Macmillan, 1983).

Mitchell, Brian R., and Phyllis Deane, Abstract of British Historical Statistics (Cambridge, UK: Cambridge University Press, 1962).

Mulligan, Casey B., "Pecuniary Incentives to Work in the U. S. during World War II," Journal of Political Economy, CVI (1998), 1033-1077.

Rietz, Thomas A., "The Equity Risk Premium: A Solution," Journal of Monetary Economics, XXII (1988), 117-131.

Romer, Christina, "World War I and the Postwar Depression: A Reinterpretation Based on Alternative Estimates of GNP," Journal of Monetary Economics, XXII (1988), 91-115.

"The Prewar Business Cycle Reconsidered: New Estimates of Gross National Product, 1869-1908," Journal of Political Economy, XCVII (1989), 1-37.

Rossi, Nicola, Andrea Sorgato, and Gianni Toniolo, "I Conti Economici Italiani: Una Ricostruzione Statistica, 1890-1990," Revista di Storia Economica, X (1993), 1-47.

Santa-Clara, Pedro, and Shu Yan, "Jump and Volatility Risk and Risk Premia: A New Model and Lessons from S\&P 500 Options," unpublished, University of California Los Angeles, June 2005.

Slemrod, Joel, "Saving and the Fear of Nuclear War," Journal of Conflict Resolution, XXX (1986), 403-419.

Taylor, Bryan, "GFD Guide to Total Returns on Stocks, Bonds and Bills," available on the Internet from Global Financial Data at www.globalfindata.com, 2005.

Urquhart, M. C., Gross National Product, Canada, 1870-1926-the Derivation of the Estimates (Kingston and Montreal, Canada: McGill-Queen's University Press, 1993).

U. S. Department of Commerce, Historical Statistics of the United States, Colonial Times to 1970 (Washington, DC: U. S. Government Printing Office, 1975).

Weitzman, Martin L., "A Unified Bayesian Theory of Equity 'Puzzles', unpublished, Harvard Unniversity, March 2005. 